\title{
Effects of lipopolysaccharide dosing on bacterial community composition and fermentation in a dual-flow continuous culture system
}

\author{
X. Dai, ${ }^{1}$ E. M. Paula, ${ }^{1}$ A. L. J. Lelis, ${ }^{1}$ L. G. Silva, ${ }^{1}$ V. L. N. Brandao, ${ }^{1}$ H. F. Monteiro, ${ }^{1}$ P. Fan, ${ }^{1}$ S. R. Poulson, ${ }^{2}$ \\ K. C. Jeong, ${ }^{1}$ and A. P. Faciola ${ }^{1 *}$ \\ ${ }^{1}$ Department of Animal Sciences, University of Florida, Gainesville 32611 \\ ${ }^{2}$ Department of Geological Sciences and Engineering, University of Nevada, Reno 89557
}

\section{ABSTRACT}

The objectives of this study were to evaluate the effects of lipopolysaccharide (LPS) dosing on bacterial fermentation and bacterial community composition (BCC), to set up a subacute ruminal acidosis (SARA) nutritional model in vitro, and to determine the best sampling time for LPS dosing in a dual-flow continuous culture system. Diets were randomly assigned to 6 fermentors in a replicated $3 \times 3$ Latin square with three 11-d experimental periods that consisted of 7 $\mathrm{d}$ for diet adaptation and $4 \mathrm{~d}$ for sample collection. Treatments were control diet (CON), wheat and barley diet (WBD) to induce SARA, and control diet + LPS (LPSD). Fermenters were fed $72 \mathrm{~g}$ of dry matter/d. The forage:concentrate ratio of CON was 65:35. The WBD diet was achieved by replacing $40 \%$ of dry matter of the CON diet with $50 \%$ ground wheat and $50 \%$ ground barley. The LPS concentration in LPSD was 200,000 endotoxin units, which was similar to that observed in cows with SARA. The SARA inducing and LPS dosing started at $\mathrm{d} 8$. The $\mathrm{BCC}$ was determined by sequencing the V4 region of the $16 \mathrm{~S}$ rRNA gene using the Illumina MiSeq platform (Illumina Inc., San Diego, CA). The LPSD and CON maintained $\mathrm{pH}$ above 6 for the entire experimental period, and the WBD kept $\mathrm{pH}$ between 5.2 and 5.6 for $4 \mathrm{~h} / \mathrm{d}$, successfully inducing SARA. Digestibility of neutral detergent fiber and crude protein in LPSD were not different from WBD but tended to be lower than CON. Lipopolysaccharide dosing had no effect on pool of VFA concentrations and profiles but decreased bacterial $\mathrm{N}$; the pattern changes of VFA and LPS in LPSD started to increase and be similar to WBD 6 h after LPS dosing. Pool of LPS concentration was around 11-fold higher in WBD and 4-fold higher in LPSD than CON. In the solid fraction, the BCC of LPSD was different from WBD and tended to be dif-

Received March 23, 2018.

Accepted August 27, 2018.

*Corresponding author: afaciola@ufl.edu ferent from CON. In the liquid fraction, the BCC was different among treatments. The LPS dosing increased the relative abundance of Succinimonas, Anaeroplasma, Succinivibrio, Succiniclasticum, and Ruminobacter, which are main gram-negative bacteria related to starch digestion. Our results suggest that LPS dosing does not affect $\mathrm{pH}$ alone. However, LPS could drive the development of SARA by affecting bacteria and bacterial fermentation. For future studies, samples are suggested to be taken $6 \mathrm{~h}$ after LPS dosing in a dualflow continuous culture system.

Key words: in vitro, gram-negative bacteria, starch digesting bacteria, $16 \mathrm{~S}$ rRNA

\section{INTRODUCTION}

Subacute ruminal acidosis is a metabolic disorder characterized by episodes of ruminal $\mathrm{pH}$ below 5.6 for more than $180 \mathrm{~min} / \mathrm{d}$ (Gozho et al., 2005). Subacute ruminal acidosis has been associated with reduced feed intake, milk production, diarrhea, milk fat depression, liver abscesses, and laminitis (Plaizier et al., 2008; Plaizier et al., 2012; Kleen et al., 2013). The adverse effects of SARA are very costly and can affect cows' welfare, especially for high-producing dairy cows (Plaizier et al., 2008).

Subacute ruminal acidosis is generally caused by a combination of low-fiber diets and a large intake of rapidly fermentable carbohydrates, resulting in the accumulation of organic acids, causing ruminal $\mathrm{pH}$ depression (Britton and Stock, 1989; Owens et al., 1998; Nagaraja and Titgemeyer, 2007). However, other toxic factors, such as bacterial endotoxins, have also been suggested to play a role on pathophysiology of acidosis (Dunlop, 1972; Owens et al., 1998). Lipopolysaccharide is a highly proinflammatory compound that is the major lipidic component of the outer membrane and vital for the structural and functional integrity of gram-negative bacteria (Guerville and Boudry, 2016). Bacteria death and lysis are normal processes, and thus LPS is normally present in ruminal fluid. However, LPS concentration 
is much higher in grain-fed compared with forage-fed cattle (Nagaraja et al., 1978a; Andersen et al., 1994), especially in cows with SARA, where the LPS concentration ranges from 4- to 16-fold higher compared with cows without SARA (Gozho et al., 2007; Khafipour et al., 2009a; Li et al., 2012); thus, LPS has long been suspected to contribute to the pathogenesis of SARA (Dougherty, 1976; Huber, 1976). Moreover, LPS has been reported to stimulate the growth of gram-negative ruminal Mycoplasma in pure culture (Robinson and Hungate, 1973; Robinson et al., 1975). Therefore, we hypothesized that the accumulation of LPS in the rumen during SARA could affect bacterial community composition (BCC) and bacterial fermentation and then decrease $\mathrm{pH}$ and contribute to the development of SARA. Our objectives were to evaluate the effects of LPS dosing on $\mathrm{pH}$, bacterial fermentation, and BCC by using a dual-flow continuous culture system. Additional objectives of this study were to set up a SARA nutritional model and determine adequate sampling time to evaluate LPS dosing in a dual-flow continuous culture system.

\section{MATERIALS AND METHODS}

Animal care and handling were approved by the University of Nevada, Reno, Institutional Animal Care and Use Committee (protocol \#00588).

\section{Experimental Design and Diets}

Six dual-flow continuous culture fermentors $(1,200 \pm$ $50 \mathrm{~mL}$, Omni-Culture Plus, Virtis Co. Inc., Gardiner, NY) that were originally described by Hoover et al. (1976), and recently modified by Silva et al. (2016) and Paula et al. (2017), were used in the present study.

Treatments were arranged in a replicated $3 \times 3$ Latin square design with three 11-d experimental periods, consisting of $7 \mathrm{~d}$ of diet adaptation followed by $4 \mathrm{~d}$ sampling, and SARA inducing and LPS dosing started on d 8. Each fermentor was randomly assigned within Latin square to receive each diet once over the 3 periods. Treatments were (1) control diet $(\mathbf{C O N}) ;(2)$ wheat and barley diet inducing SARA (WBD); and (3) control diet + LPS (LPSD). The CON forage and concentrate ratio was 65:35 (DM basis). Dietary ingredients and chemical compositions of the diets are presented in Table 1. All dietary ingredients were ground through a 2-mm screen in a Wiley mill (model \#2, Arthur H. Thomas Co., Philadelphia, PA) and then alfalfa hay and orchard grass hay were pelleted.

Fermenters were fed $72 \mathrm{~g} / \mathrm{d}$ (DM basis). The control diet was formulated to meet or exceed NRC recommendations (NRC, 2001) for a Holstein dairy cow, with 680 $\mathrm{kg}$ of BW and producing $35 \mathrm{~kg}$ milk/d, $3.5 \%$ milk fat and $3.2 \%$ milk CP. The goal of the control diet was to keep the $\mathrm{pH}$ above 6 during the experiment. The SARA was induced following the modified model of Keunen et al. (2002) and Gozho et al. (2007): 40\% of the DM of CON was replaced with $50 \%$ ground wheat and $50 \%$ ground barley, which was the same inclusion level of wheat and barley used in Plaizier et al. (2017). The forage:concentrate ratio was 39:61 in WBD, which was the same forage:concentrate ratio that caused SARA in the study of Gozho et al. (2006). Two-thirds of the ground wheat and barley (WB) were fed at $1000 \mathrm{~h}$ to reduce $\mathrm{pH}$ to below 5.6, and another one-third of WB was fed at $1300 \mathrm{~h}$ to prolong the duration with $\mathrm{pH}$ below 5.6 without further $\mathrm{pH}$ depression. Meanwhile, $30 \%$ of DM intake of CON were fed separately at 0800 and $2000 \mathrm{~h}$. For the CON and LPSD, $70 \%$ of DM were fed at $0800 \mathrm{~h}$ and $30 \%$ at $2000 \mathrm{~h}$. The feeding schedule is presented in Figure 1.

\section{LPS Application}

In each experimental period, each fermentor received $24 \mathrm{mg}$ of LPS (Escherichia coli O111:B4, Sigma-Aldrich Co., St. Louis, MO) added into $6 \mathrm{~mL}$ of no-polygenic water (catalog no. W50-500, Lonza Group Ltd., Basel,

Table 1. Ingredients and chemical composition of the experimental diets (\% of DM unless otherwise stated)

\begin{tabular}{|c|c|c|c|}
\hline \multirow[b]{2}{*}{ Item } & \multicolumn{3}{|c|}{ Treatment $^{1}$} \\
\hline & $\mathrm{CON}$ & WBD & LPSD \\
\hline \multicolumn{4}{|l|}{ Ingredient composition } \\
\hline Alfalfa hay & 47.0 & 28.2 & 47.0 \\
\hline Orchard grass hay & 18.0 & 10.8 & 18.0 \\
\hline Ground corn & 28.0 & 16.8 & 28.0 \\
\hline Soybean meal & 4.02 & 2.40 & 4.02 \\
\hline Ground wheat & - & 20.0 & - \\
\hline Ground barley & - & 20.0 & - \\
\hline Mineral $\operatorname{mix}^{2}$ & 3.01 & 1.80 & 3.01 \\
\hline \multicolumn{4}{|l|}{ Chemical composition } \\
\hline $\mathrm{DM}, \%$ & 89.9 & 90.2 & 89.9 \\
\hline $\mathrm{OM}$ & 89.8 & 93.2 & 89.8 \\
\hline $\mathrm{CP}$ & 17.3 & 14.8 & 17.3 \\
\hline NDF & 32.4 & 25.8 & 32.4 \\
\hline $\mathrm{ADF}$ & 20.7 & 14.1 & 20.7 \\
\hline Starch & 17.8 & 31.1 & 17.8 \\
\hline Ether extract & 2.11 & 1.90 & 2.11 \\
\hline $\mathrm{Ca}^{3}$ & 0.80 & 0.50 & 0.80 \\
\hline $\mathrm{P}^{3}$ & 0.30 & 0.30 & 0.30 \\
\hline $\mathrm{NE}_{\mathrm{L}},{ }^{4} \mathrm{Mcal} / \mathrm{kg}$ of DM & 1.47 & 1.53 & 1.47 \\
\hline \multicolumn{4}{|c|}{$\begin{array}{l}{ }^{1} \mathrm{CON}=\text { control diet; } \mathrm{WBD}=\text { wheat and barley diet inducing SAR } \\
\mathrm{LPSD}=\text { control diet }+ \text { LPS. }\end{array}$} \\
\hline \multicolumn{4}{|c|}{$\begin{array}{l}{ }^{2} \text { Provided (per } \mathrm{kg} \text { of } \mathrm{DM} \text { ): } 955 \mathrm{~g} \text { of } \mathrm{NaCl}, 3,500 \mathrm{mg} \text { of } \mathrm{Zn}, 2,000 \mathrm{~m} \\
\text { of } \mathrm{Fe}, 1,800 \mathrm{mg} \text { of } \mathrm{Mn}, 280 \mathrm{mg} \text { of } \mathrm{Cu}, 100 \mathrm{mg} \text { of } \mathrm{I} \text {, and } 60 \mathrm{mg} \text { of } \mathrm{Co} \text {. } \\
{ }^{3} \text { Estimated according to the NRC (2001). } \\
{ }^{4} \text { Estimated using the NRC (2001) model. }\end{array}$} \\
\hline
\end{tabular}


$0800 \mathrm{~h}, 70 \%$ of CON
fed to CON and LPSD
fermentors, $30 \%$ CON
fed to WBD fermentors

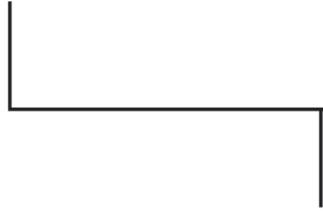

$1000 \mathrm{~h}, 2 / 3$ of WB fed to WBD fermentors and $2 / 3$ of LPS fed to LPSD fermentors
$1300 \mathrm{~h}, 1 / 3$ of WB fed to WBD fermentors and $1 / 3$ of LPS fed to LPSD fermentors

Figure 1. Experimental feeding schedule. $\mathrm{CON}=$ control diet; LPSD $=$ control diet $+\mathrm{LPS} ; \mathrm{WB}=$ wheat and barley; WBD $=$ wheat and barley diet inducing SARA.

Switzerland), to generate $4 \mathrm{mg} / \mathrm{mL}$ of LPS, which is equal to $200,000 \mathrm{EU}$ of $\mathrm{LPS}(1 \mathrm{ng} / \mathrm{mL}=10$ endotoxin units based on the Sigma-Aldrich protocol and considering an average volume of fermentors of $1,200 \mathrm{~mL}$ ). The concentration of LPS (200,000 EU) was chosen based on previous studies where the concentration of LPS was measured in the cows with SARA (Gozho et al., 2007; Khafipour et al., 2009a,b). Dosing of LPS followed the SARA induced model: $4 \mathrm{~mL}$ of $4 \mathrm{mg} / \mathrm{mL}$ of LPS was infused into the 2 fermentors at $1000 \mathrm{~h}$ and another $2 \mathrm{~mL}$ of $4 \mathrm{mg} / \mathrm{mL}$ of LPS was infused at 1300 $\mathrm{h}$ by no-polygenic syringe (Becton, Dickinson and Co., Franklin Lakes, NJ).

\section{Dual-Flow Continuous Culture System Operation}

Ruminal fluid was collected $2 \mathrm{~h}$ after morning feeding from 2 ruminally cannulated Angus steers (3 yr old, raised on $100 \%$ grass hay diets for their entire lives) fed the same forage:concentrate radio as the experimental diets, containing $65 \%$ alfalfa hay, $35 \%$ concentrate, and ad libitum mineral mixture for 2 wk before the experiment. The ruminal digesta was collected from the ventral, central, and dorsal areas of the rumen, and then strained through 4 layers of cheesecloth, and approximately $10 \mathrm{~L}$ of ruminal fluid was stored into pre-warmed thermal containers. Ruminal fluid was homogenized, infused with $\mathrm{N}_{2}$ to maintain the anaerobic environment, and kept at $39^{\circ} \mathrm{C}$ in a pre-heated water bath.

About 1,200 $\mathrm{mL}$ of ruminal fluid was poured into each fermentor until it cleared the overflow spout. During the entire experiment, fermentors were maintained at $39^{\circ} \mathrm{C}$ and $\mathrm{N}_{2}(40 \mathrm{~mL} / \mathrm{min})$ was continuously infused to maintain anaerobic conditions. The fermentor content was continuously agitated by a central propeller apparatus driven by magnets at a rate of $155 \mathrm{rpm}$. Artificial saliva (Weller and Pilgrim, 1974) containing $0.4 \mathrm{~g} / \mathrm{L}$ of urea was used to simulate recycled $\mathrm{N}$ and was continuously infused at $2.2 \mathrm{~mL} / \mathrm{min}$ into vessels. Saliva and liquid flow rate were measured twice daily for consistency. The solid dilution (5.5\%) and liquid dilution rate $(11.0 \%)$ were maintained constantly by regulating buffer input and solid and liquid removal, to mimic in vivo passage rates.

\section{Experimental Procedures and Sample Collections}

On d 5, liquid and solid effluents were homogenized and collected to determine the abundance of background ${ }^{15} \mathrm{~N}$ (Calsamiglia et al., 1996). Subsequently, $0.077 \mathrm{~g}$ of $10.2 \%$ excess of $\left({ }^{15} \mathrm{NH}_{4}\right)_{2} \mathrm{SO}_{4}$ (Sigma-Aldrich Co.) was dosed into each fermentor to instantaneously label the $\mathrm{NH}_{3}-\mathrm{N}$ pool. Saliva was reformulated and $0.077 \mathrm{~g} / \mathrm{L}$ of enriched $\left({ }^{15} \mathrm{NH}_{4}\right)_{2} \mathrm{SO}_{4}$ was infused in replacement of isonitrogenous quantities of urea to maintain a steadystate ${ }^{15} \mathrm{~N}$ enrichment concentration inside each fermentor (Calsamiglia et al., 1996).

On $\mathrm{d} 8,9,10$, and $11, \mathrm{pH}$ was measured with a $\mathrm{pH}$ meter (Accumet portable AP61, Fisher Scientific, Atlanta, GA) every hour after morning feeding. Once the $\mathrm{pH}$ was below 5.6, $\mathrm{pH}$ was measured every half hour to be more precisely determine the exact sustained time of $\mathrm{pH}$ below 5.6. After feeding at $2000 \mathrm{~h}$, pH was measured every hour until the $\mathrm{pH}$ of all fermenters was higher than 5.6.

On d 5, approximately two-thirds of the effluent containers were submerged in a chilled water bath $\left(<4^{\circ} \mathrm{C}\right)$ to prevent further microbial fermentation. On d $8,9,10$, and 11 , bacteria samples were collected at $2,5,7$, and $9 \mathrm{~h}$ after morning feeding per sampling day (Figure 2). Briefly, for each sampling time, $12 \mathrm{~mL}$ of 


\section{0:00 - Before putting the first proportion WB/LPS into fermentors}

$15: 00-7 \mathrm{~h}$ after morning feeding

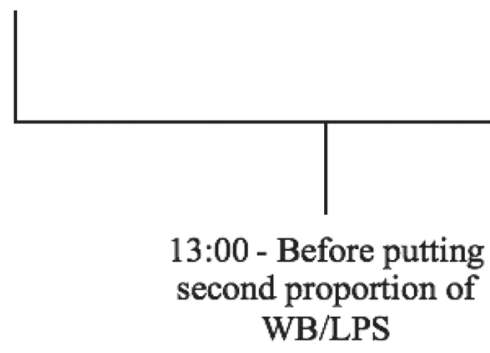

$17: 00$ - $9 \mathrm{~h}$ after morning feeding

Figure 2. Particle-associated and liquid-associated bacteria (ruminal bacteria) collection. WB = wheat and barley.

liquid was collected from liquid effluent container for $4 \mathrm{~d}$, totaling $48 \mathrm{~mL}$ from the same sampling time and the same fermentor, which were pooled into a $50-\mathrm{mL}$ centrifuge tube. At the same time, solid particles (200 $\mathrm{mL}$ ) were collected from solid effluent containers and strained through 4 layers of cheesecloth. During 4 sampling days, totaling $25 \mathrm{~g}$ of solid samples, which were combined per fermentor per sampling time. Liquid and solid samples were stored at $-80^{\circ} \mathrm{C}$ for further DNA extraction. Sampling schedule is presented in Figure 2.

On d 8, 9, 10, and 11, during each bacterial sampling time, $50 \mathrm{~mL}$ of liquid and $50 \mathrm{~mL}$ of solid effluents per fermentor per sampling time were also taken from containers, homogenized, and pooled into digesta collecting containers, during 4 sampling times, totaling $400 \mathrm{~mL}$ of pooled digesta, which were collected per fermentor per sampling day and stored at $-20^{\circ} \mathrm{C}$. The following morning before feeding, liquid and solid effluents from each container were taken and homogenized and $400 \mathrm{~mL}$ was removed via vacuum system into the same digesta collecting containers and stored at $-20^{\circ} \mathrm{C}$ for further analysis of $\mathrm{DM}, \mathrm{OM}, \mathrm{CP}, \mathrm{NDF}, \mathrm{ADF}$, ether extract, starch, and ash.

An additional two 8-mL digesta effluent subsamples were filtered through 4 layers of cheesecloth for analysis of a pool of $\mathrm{NH}_{3}-\mathrm{N}$ and VFA before morning feeding.
Samples used for $\mathrm{NH}_{3}-\mathrm{N}$ and VFA analyses were preserved with $2 \mathrm{~mL}$ of $25 \%$ metaphosphoric acid. After that, samples were centrifuged at 12,000 $\times g$ for 15 min at $4^{\circ} \mathrm{C}$, and the supernatant was collected and stored at $-20^{\circ} \mathrm{C}$ for subsequent analysis. Another additional 10-mL digesta effluents subsample from each fermentor was collected and filtered through 4 layers of cheesecloth for LPS and lactate analyses. The collected samples were prepared as described by Gozho et al. (2005) and stored at $-20^{\circ} \mathrm{C}$ for subsequent LPS and lactate concentration analyses.

On d 8, 9, 10, and 11, two 8-mL digesta effluents samples were collected at $0,2,4,5,6,7,8$, and $9 \mathrm{~h}$ after morning feeding and preserved with $2 \mathrm{~mL}$ of $25 \%$ metaphosphoric acid to determine the diurnal variation of $\mathrm{NH}_{3}-\mathrm{N}$ and VFA concentrations. Another 10 $\mathrm{mL}$ of digesta effluent samples was collected at 0,4 , 6,8 , and $9 \mathrm{~h}$ after morning feeding to determine the diurnal variation of LPS concentration. The sampling procedure is presented in Figure 3.

On the last day of each experimental period, bacterial samples were collected according to the modified method of Krizsan et al. (2010) and described in detail in Brandao et al. (2018). The bacterial samples were freeze-dried, grounded by a mortar pestle, and later analyzed for ${ }^{15} \mathrm{~N}$ enrichment, total $\mathrm{N}$, and DM.

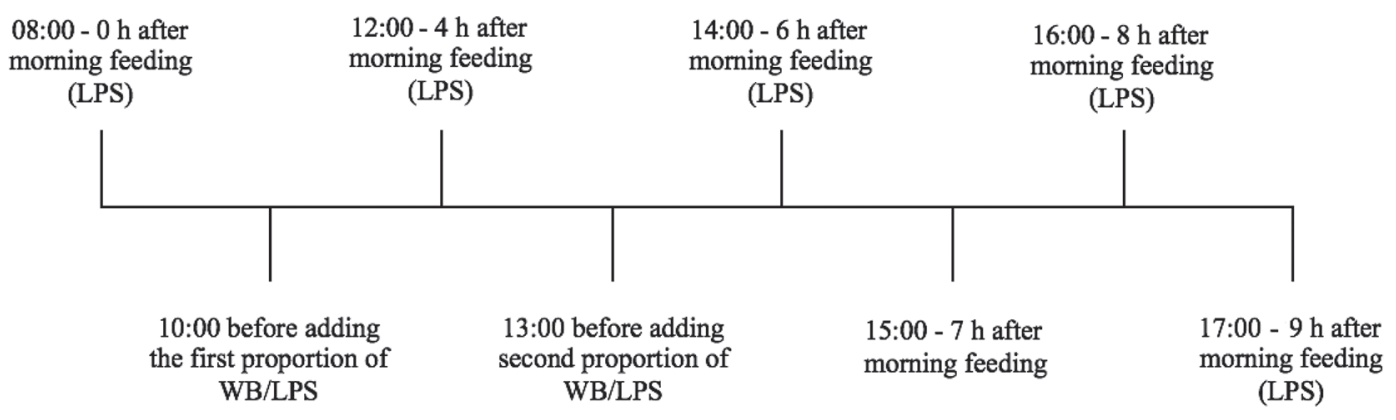

Figure 3. Sample collection schedule of VFA, $\mathrm{NH}_{3}$, and LPS. WB = wheat and barley. 


\section{Ammonia and VFA Analyses}

Digesta effluent samples were analyzed for $\mathrm{NH}_{3}-\mathrm{N}$ concentration (Chaney and Marbach, 1962) and VFA concentrations were analyzed by capillary GC (Agilent 6890N, Agilent Technologies, Santa Clara, CA) equipped with a capillary column (HP-FFAP, $10 \mathrm{~m}$ by $530 \mu \mathrm{m}$ by $1.00 \mu \mathrm{m}$ film thickness, Agilent Technologies), as described in Brandao et al. (2018).

\section{Lactate Analysis}

The UV method was used for the determination of Dand L-lactic acid in effluent samples by using D-lactic acid/L-lactic acid kit from R-Biopharm (R-Biopharm AG, Darmstadt, Germany). The analysis procedure was adapted from the manufactor's protocol. Specifically, $20 \mu \mathrm{L}$ of digesta samples, $80 \mu \mathrm{L}$ of deionized water, $100 \mu \mathrm{L}$ mix of glycylglycine buffer and L-glutamic acid, $20 \mu \mathrm{L}$ of NAD, and $2 \mu \mathrm{L}$ of glutamate-pyruvate transaminase suspension were loaded in a 96-well UV microplate, incubated at room temperature for $5 \mathrm{~min}$, and read at $340 \mathrm{~nm}$ on a microplate spectrophotometer (Spectra Max 340 PC, Molecular Devices Corporation, Sunnyvale, CA). Then, $2 \mu \mathrm{L}$ of D-lactate dehydrogenase solution was added to each well and incubated in room temperature for $180 \mathrm{~min}$ and absorbance was read to determine the concentration of D-lactic acid. Then $2 \mu \mathrm{L}$ of L-lactate dehydrogenase solution was added to each well and incubated in room temperature for another $180 \mathrm{~min}$, and absorbance was read to determine the concentration of L-lactic acid. A $99 \%$ of recovery of spiked concentration for both D- and L-lactic acid was considered as noninhibitory dilution.

\section{LPS Concentration Analysis}

Free LPS in rumen fluid was measured by a chromogenic kinetic Limulus amebocyte lysate assay (KineticQCL, Lonza Group Ltd.) in a 96-well microplate using an microplate spectrophotometer (Spectra Max 340 PC, Molecular Devices Corp.) as described by Khafipour et al. (2009b). Rumen fluid samples were diluted 1:10,000, with the final dilution made of $50 \%$ diluted sample and 50\% $\beta$-glucan blocker (catalog no. N190, Lonza Group Ltd.).

\section{DNA Extraction}

Total genomic DNA was extracted separately from solid and liquid samples following the methods of Stevenson and Weimer (2007) and described by Dai et al. (2017). This method is similar to the phenol-chloroform with bead beating II method (Henderson et al., 2013), which is likely to yield DNA representative of the BCC.
The DNA was quantified by Qubit Fluorometer (Invitrogen, San Diego, CA) and stored at $-80^{\circ} \mathrm{C}$ following extraction.

\section{DNA Amplification, Library Preparation, and Sequencing}

The V4 variable region of the bacterial 16S rRNA gene was amplified following Kozich et al. (2013). A random row of 12 samples was selected from each PCR plate and run on a $1 \%$ agarose gel to confirm success of the PCR. The amplicons were then normalized by using SequalPrep Normalization Plate Kit (Applied Biosystems, Foster City, CA), and then to pool a library. The library was then diluted to $4 \mathrm{nM}$ and processed according to the standard Illumina MiSeq sequencing protocol for $2 \times 300$ cycles V3 reagents, using 10 pM clustering concentrations and 20\% PhiX spike-in control. Approximately 50 million paired-end reads $(\% \geq \mathrm{Q} 30$ reads of $\sim 70 \%$ ) were obtained. All sequences from this project have been deposited in the National Center for Biotechnology Information Short Read Archive under accession number SRP151735.

\section{Chemical Analyses}

Feed and effluent samples were analyzed for DM (method 934.01), ash (method 938.08), and ether extract (method 920.85) according to AOAC (1990). The OM was calculated as the difference between DM and ash contents. Feed and effluent samples CP was determined using a Leco combustion $\mathrm{N}$ analyzer (Leco CN628 Carbon/N Analyzer, Leco Instruments Inc., St. Joseph, MI; method 990.13, AOAC International, 2005). The NDF and ADF samples were sequentially analyzed, treated with thermo-stable $\alpha$-amylase, according to Van Soest et al. (1991), and adapted for the Ankom ${ }^{200}$ Fiber Analyzer (Ankom Technology, Macedon, NY). The starch analysis for both feed and effluent samples followed the procedure described by Hall et al. (2015).

Background and bacterial samples were analyzed for DM, N, and ash as previously described for feed and effluent samples, and analyzed for ${ }^{15} \mathrm{~N}$ enrichment according to the method of Werner et al. (1999). Isotope analyses were done using a Eurovector model 3000 (Euro EA 3000, Eurovector S.P.A., Milano, Italy) elemental analyzer interfaced to a Micromass Isoprime (IsoPrime, Micromass UK Ltd., Manchester, UK) stable isotope ratio mass spectrometer.

\section{Bacterial Sequence Data Analysis}

Sequence processing and data analysis were performed using mothur v.1.38.1 following the MiSeq SOP 
(Kozich et al., 2013) and described in detail by Dai et al. (2017). Briefly, the unique sequences were aligned against the SILVA $16 \mathrm{~S}$ rRNA gene reference alignment database (v128, Pruesse et al., 2007) and operational taxonomic units (OTU) classified based on the GreenGenes database (Desantis et al., 2006), August 2013 release, with a bootstrap cutoff of 80 . Any OTU found with $<2$ sequences in the total data set were removed. Chimeras were detected and removed by chimera. vsearch and remove.seqs (Supplemental File S1; https: //doi.org/10.3168/jds.2018-14807). The OTU were clustered into $97 \%$ identity threshold using the average neighbor algorithm. All samples were normalized by subsampling to 48,000 sequences, the size of the smallest sample. Richness (Chao 1 and Ace), diversity (Shannon, inverse Simpson), OTU counts, and coverage metrics were obtained from normalized data.

Differences in taxonomic profiles were assessed at phylum, family, genus, and OTU level in both liquid and solid phases by using Python v 3.6.0 as described in Dai et al. (2017). Only average relative abundances higher than $0.1 \%$ across all samples were further considered. The top 100 OTU were determined based on the average of relative abundance across all samples. The relative abundance of each OTU was higher than $0.1 \%$, and the relative abundance of the top $100 \mathrm{OTU}$ was around $74 \%$ of total across the treatments. Within the top 100 OTU, only the OTU significantly affected by treatments were selected to generate the heatmaps and phylogenetic tree as described in Dai et al. (2017).

\section{Statistical Analysis}

All data were subjected to least squares ANOVA using the MIXED procedure of SAS (version 9.4, SAS Institute Inc., Cary, NC). All data were checked for the linear model assumption. The relative abundance of top 100 OTU were not consistently distributed and thus were log-transformed to be consistently and normally distributed. The statistical model used was

$$
\mathrm{Y}_{\mathrm{ijk} \mathrm{l}}=\mu+\mathrm{S}_{\mathrm{i}}+\mathrm{LS}_{\mathrm{j}}+\mathrm{P}_{\mathrm{k}}+\varepsilon_{\mathrm{ijk}}
$$

where $Y_{\mathrm{ijkl}}=$ the dependent variable; $\mu=$ the overall mean; $S_{i}=$ the fixed effect of treatments; $L_{\mathrm{j}}=$ the fixed effect of Latin square; $\mathrm{P}_{\mathrm{k}}=$ the fixed effect of period; and $\varepsilon_{\mathrm{ijk}}=$ the random error. Fermenter was considered as random effect.

Data from different time points $\left(\mathrm{pH}, \mathrm{VFA}, \mathrm{NH}_{3}-\mathrm{N}\right.$, relative abundance of bacteria) were included as repeated measures. The statistical model was

$$
\mathrm{Y}_{\mathrm{ijkl}}=\mu+\mathrm{S}_{\mathrm{i}}+\mathrm{T}_{\mathrm{j}}+(\mathrm{S} \times \mathrm{T})_{\mathrm{ij}}+\mathrm{LS}_{\mathrm{k}}+\mathrm{P}_{\mathrm{m}}+\varepsilon_{\mathrm{ijklm}},
$$

where $Y_{\mathrm{ijk}}=$ dependent variable; $\mu=$ overall mean; $S_{i}=$ fixed effect of treatments; $T_{j}=$ fixed effect of time; $(\mathrm{S} \times \mathrm{T})_{\mathrm{ij}}=$ interaction between treatment and time; $\mathrm{LS}_{\mathrm{k}}=$ fixed effect of Latin square; $\mathrm{P}_{\mathrm{m}}=$ fixed effect of period and $\varepsilon_{\mathrm{ijklm}}=$ random error. Fermenter was considered as random effect. The heterogeneous compound symmetry was used as covariance structure for $\mathrm{pH}, \mathrm{VFA}$, and $\mathrm{NH}_{3}-\mathrm{N}$ analysis. The variance components were used as covariance structure to determine the relative abundance of bacteria. Different covariance structures were tested and the one with the lowest Akaike information criterion values were chosen.

The statistical analysis of $\beta$ diversity of bacterial community composition were carried out in $\mathrm{R}$ (vegan package; Oksanen et al., 2015). Total bacterial community structure (Bray-Curtis) and composition (Jaccard) were calculated from normalized OTU data and visualized by nonmetric multidimensional scaling plots. The PERMANOVA was run to determine the differences in community structure and composition between the phases (liquid or solid) and treatments by using the "adonis" function in "vegan," with the BenjaminiHochberg correction for multiple comparisons when necessary. All data were expressed as the least squares means \pm standard error of the mean and considered significant if $P \leq 0.05$, with tendencies identified if 0.05 $<P \leq 0.10$.

\section{RESULTS}

\section{$\mathrm{pH}$}

The diurnal variation of $\mathrm{pH}$ among treatments is presented in Figure 4. The $\mathrm{pH}$ of CON was higher than 6 for the entire experimental period, which met our expectation of CON. The $\mathrm{pH}$ of WBD was kept between 5.2 and 5.6 for $4 \mathrm{~h}$ every sampling day, successfully inducing SARA. The LPS dosing had no effect on the $\mathrm{pH}$. The $\mathrm{pH}$ pattern of LPSD was similar to CON, which was higher than 6 for the entire experimental periods.

\section{Digestibility and Fermentation Parameters}

Digestibility of DM, OM, ADF, and starch were not different among treatments; however, NDF $(P=0.10)$ and CP $(P=0.10)$ digestibility of LPSD tended to be lower than CON, but no difference was observed between LPSD and WBD (Table 2).

Pool of total VFA concentration and molar proportion of propionate, valerate, isovalerate, and the concentration of BCVFA were not different among treatments (Table 3). A decrease was observed in the proportion of acetate and acetate:propionate ratio, whereas an increase in molar proportion of butyrate was observed 


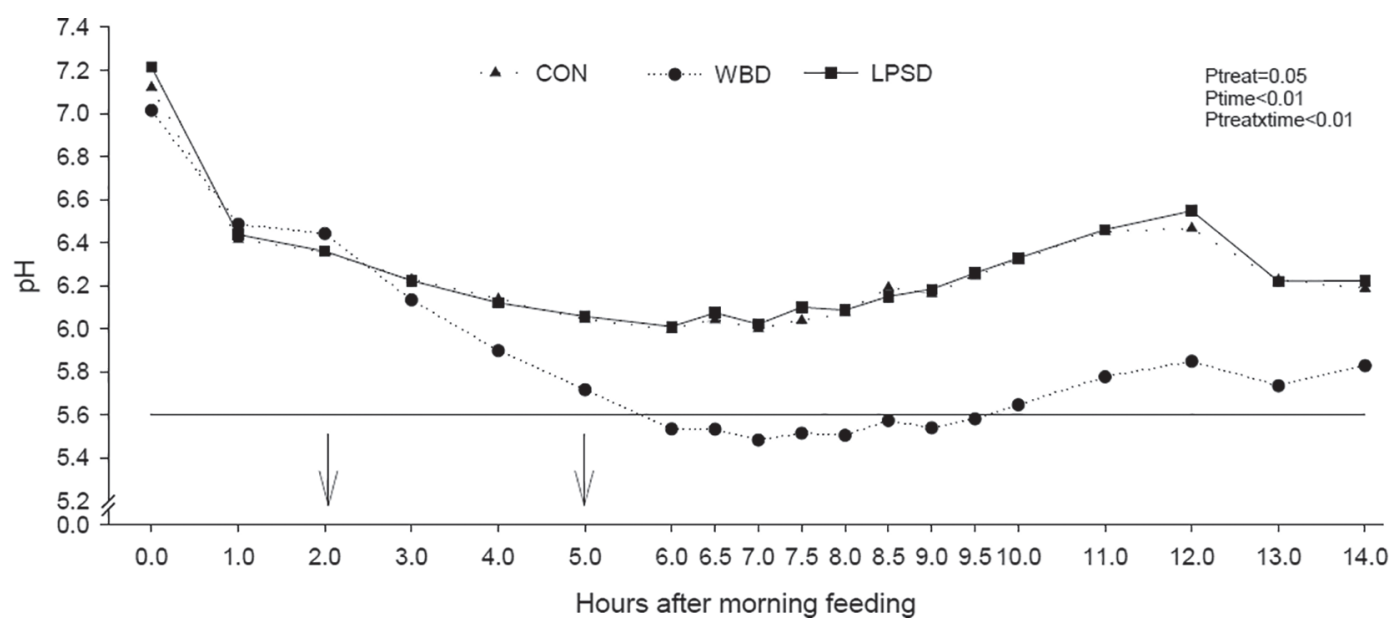

Figure 4. Effects of LPS on diurnal variation of $\mathrm{pH}$ in a dual-flow continuous culture system. $\mathrm{CON}=$ control diet; WBD $=$ wheat and barley diet inducing SARA; LPSD = control diet + LPS. Arrows represent the time of wheat and barley and LPS dosing. Ptreat $=$ effect of treatments; Ptime $=$ effect of time; Ptreat $\times$ time $=$ interaction between treatment and time.

in WBD when compared with CON; however, no difference was observed between LPSD and CON. The molar proportion of isobutyrate $(P=0.08)$ tended to be the lowest whereas the lactate concentration $(P=0.10)$ tended to be the highest in WBD, and no differences were observed between LPSD and CON.

Diurnal variation of VFA among treatments is presented in Figure 5. A significant interaction was present between treatments and time on concentrations of total VFA, acetate, propionate, butyrate, and isobutyrate. Concentration of total VFA, acetate, and propionate of WBD started to be lower than LPSD and CON $4 \mathrm{~h}$ after morning feeding, and the concentration of butyrate was higher than LPSD and CON $8 \mathrm{~h}$ after morning feeding (Figure 5, panels A, B, C, D, and F). Six hours after LPS dosing ( $8 \mathrm{~h}$ after morning feeding), the concentrations of total VFA, acetate, propionate, butyrate, and isobutyrate were not different between LPSD and WBD and the patterns of these VFA in LPSD started to be similar to WBD. Treatment and

Table 2. Effects of LPS dosing on nutrient true digestibility of DM, $\mathrm{OM}, \mathrm{CP}, \mathrm{NDF}, \mathrm{ADF}$, and starch in a dual-flow continuous culture system

\begin{tabular}{lrrrrr}
\hline \multirow{2}{*}{$\begin{array}{l}\text { Digestibility, } \\
\%\end{array}$} & \multicolumn{3}{c}{ Treatment $^{1}$} & & \\
\cline { 2 - 4 } & CON & WBD & LPSD & SEM & $P$-value \\
\hline DM & 59.6 & 58.6 & 57.1 & 1.03 & 0.28 \\
OM & 60.4 & 59.4 & 57.9 & 1.18 & 0.29 \\
CP & 50.8 & 44.3 & 45.8 & 2.46 & 0.10 \\
NDF & 56.0 & 49.7 & 50.2 & 1.83 & 0.10 \\
ADF & 63.3 & 59.1 & 58.5 & 1.45 & 0.11 \\
Starch & 79.9 & 80.3 & 82.5 & 2.30 & 0.71 \\
\hline
\end{tabular}

${ }^{1} \mathrm{CON}=$ control diet; $\mathrm{WBD}=$ wheat and barley diet inducing SARA; LPSD $=$ control diet + LPS. treatment $\times$ time had no effects on the concentration of valerate, isovalerate, and BCVFA; however, $6 \mathrm{~h}$ after LPS dosing, LPSD and WBD started to have similar patterns (Figure 5, panels E, G, and $\mathrm{H}$ ). Meanwhile, $8 \mathrm{~h}$ after morning feeding ( $6 \mathrm{~h}$ after LPS dosing), the concentration of total VFA and individual VFA started to increase in both LPSD and WBD.

Pool of LPS concentration was not different between LPSD and CON but lower than WBD (Table 3). Concentration of LPS in WBD was around 11-fold higher than CON, and LPS concentration in LPSD was around 4-fold higher than CON. There were significant

Table 3. Effects of LPS dosing on the LPS concentration and shortchain fatty acid concentrations and molar proportion in pooled effluent in a dual-flow continuous culture system

\begin{tabular}{lccccrr}
\hline & \multicolumn{3}{c}{ Treatment $^{1}$} & & \\
\cline { 2 - 4 } Item & CON & WBD & LPSD & SEM & $P$-value \\
\cline { 2 - 5 } & & & & & \\
LPS, EU ${ }^{2} / \mathrm{mL}$ & $1,898^{\mathrm{b}}$ & $20,770^{\mathrm{a}}$ & $6,712^{\mathrm{b}}$ & 3,111 & $<0.01$ \\
Total VFA, $\mathrm{m} M$ & 84.7 & 81.3 & 83.7 & 1.34 & 0.23 \\
Molar proportion, $\%$ & & & & & \\
$\quad$ Acetate & $65.9^{\mathrm{a}}$ & $56.8^{\mathrm{b}}$ & $64.8^{\mathrm{a}}$ & 1.13 & $<0.01$ \\
Propionate & 18.4 & 19.8 & 18.8 & 0.53 & 0.15 \\
Butyrate & $12.6^{\mathrm{b}}$ & $20.0^{\mathrm{a}}$ & $14.0^{\mathrm{b}}$ & 1.28 & $<0.01$ \\
Isobutyrate & 0.50 & 0.43 & 0.51 & 0.03 & 0.08 \\
Valerate & 1.63 & 1.62 & 1.57 & 0.02 & 0.13 \\
$\quad$ Isovalerate & 0.98 & 0.91 & 0.81 & 0.08 & 0.23 \\
Lactate, m $M$ & 0.25 & 1.07 & 0.27 & 0.27 & 0.10 \\
Total BCVFA, ${ }^{3} \mathrm{~m} M$ & 1.48 & 1.34 & 1.32 & 0.10 & 0.35 \\
Acetate:propionate & $3.59^{\mathrm{a}}$ & $2.92^{\mathrm{b}}$ & $3.45^{\mathrm{a}}$ & 0.08 & $<0.01$ \\
\hline
\end{tabular}

$\overline{\mathrm{a}, \mathrm{b}}$ Least squares means within the same row with different superscripts differ $(P<0.05)$.

${ }^{1} \mathrm{CON}=$ control diet; $\mathrm{WBD}=$ wheat and barley diet inducing SARA; LPSD $=$ control diet + LPS

${ }^{2} \mathrm{EU}=$ endotoxin units.

${ }^{3} \mathrm{BCVFA}=$ branched-chain volatile fatty acids. 
interactions of treatment and time on LPS concentration (Figure 6). Lipopolysaccharide concentration in CON was low and quite stable. Concentration of LPS sharply increased $6 \mathrm{~h}$ after morning feeding and then decreased in both LPSD and WBD. Pattern of LPS concentration in LPSD and WBD started to be similar and increased $6 \mathrm{~h}$ after LPS dosing $(8 \mathrm{~h}$ after morning feeding), following a similar pattern as VFA profiles.

The treatments had no effects on total $\mathrm{N}$ and bacterial efficiency (Table 4). The lowest $\mathrm{NH}_{3}-\mathrm{N}$ and highest NAN was observed in WBD and no difference was observed between LPSD and CON. Dosing of LPS decreased bacterial $\mathrm{N}$.

\section{Bacterial Sequence Data Summary}

Sequence coverage sufficiently met a Good's coverage greater than $99 \%$ for all samples. Across all samples, 3,129 OTU were identified. In total, $94 \%$ of OTU were classified at the phyla level, $85 \%$ at the family level, and $66 \%$ at the genus level. A total of 20 phyla were identified within the bacterial population from all samples.
A.

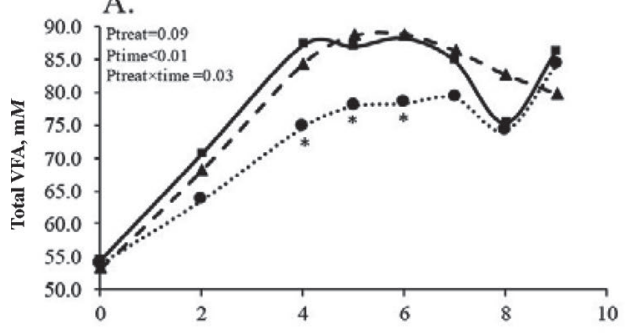

C.
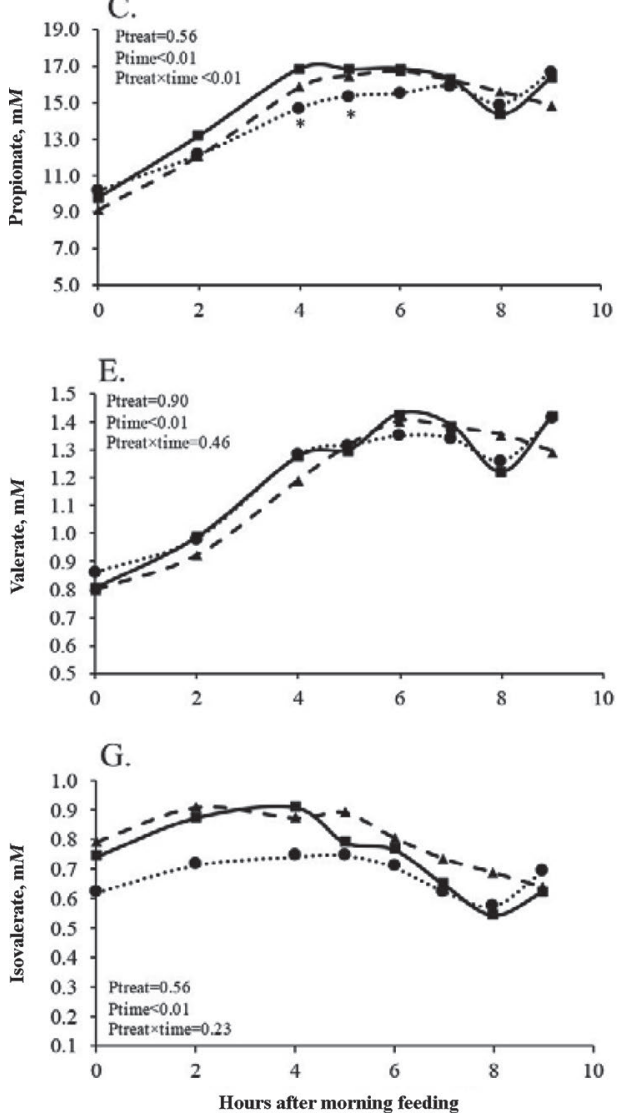

-5 CON

..... WBD

$\rightarrow$ LPSD

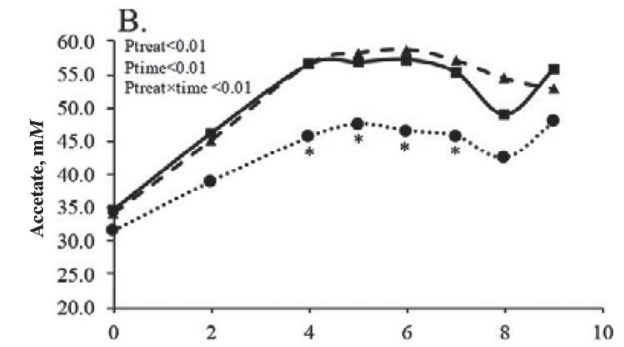

D.
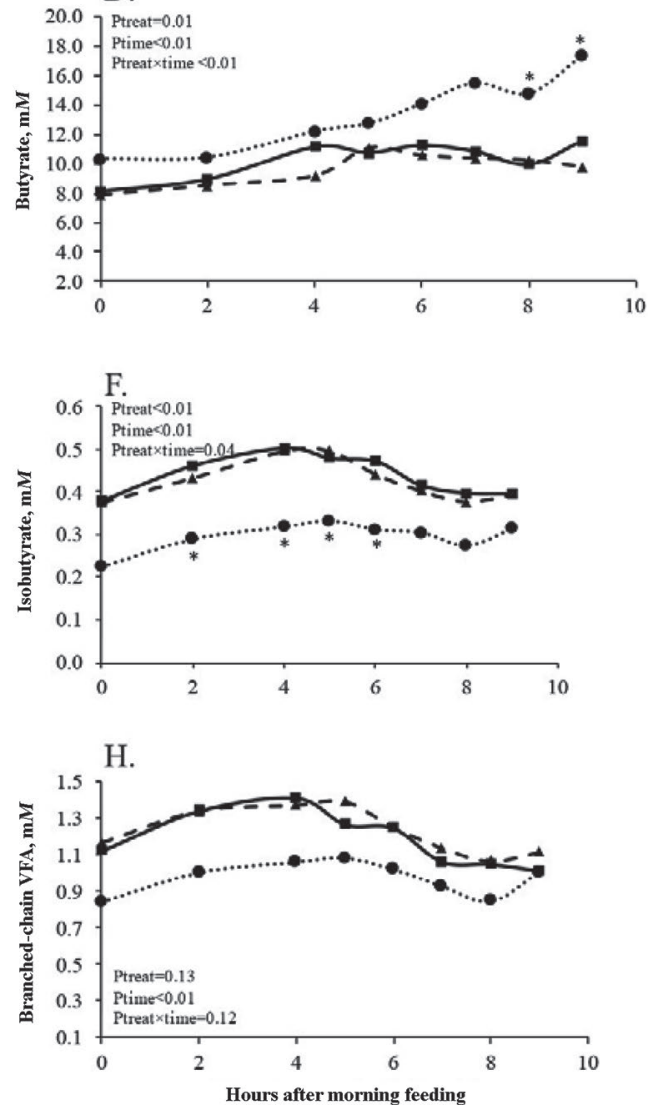

Figure 5. Effect of LPS on diurnal variation of VFA concentration in a dual-flow continuous culture system. CON $=$ control diet; WBD $=$ wheat and barley diet inducing SARA; LPSD $=$ control diet + LPS. *Difference among treatments at the time point. Ptreat $=$ effect of treatments; Ptime $=$ effect of time; Ptreat $\times$ time $=$ interaction between treatment and time. 


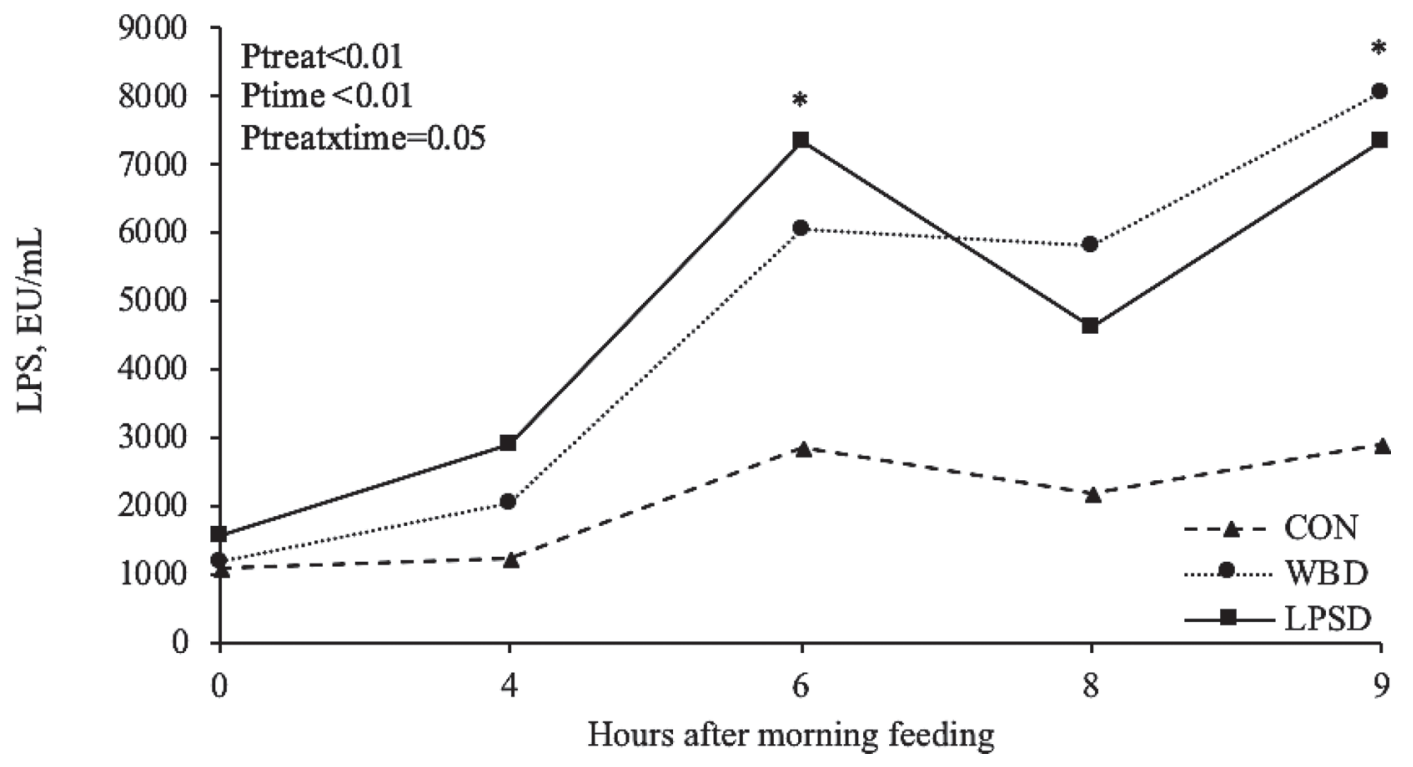

Figure 6. Effects of LPS [endotoxin units $(\mathrm{EU}) / \mathrm{mL}$ ] on diurnal variation of LPS concentration in a dual-flow continuous culture system. $\mathrm{CON}=$ control diet; $\mathrm{WBD}=$ wheat and barley diet inducing SARA; LPSD $=$ control diet + LPS. *Difference among treatments at the time point. Ptreat $=$ effect of treatments; Ptime $=$ effect of time; Ptreat $\times$ time $=$ interaction between treatment and time.

Most samples were dominated by sequences belonging to the Bacteroidetes and Firmicutes across all treatments, representing of 48 and $29 \%$ of total sequences, respectively. A total of 111 families were identified and the families Prevotellaceae, Lachnospiraceae, and Spi-

Table 4. Effects of LPS dosing on nitrogen metabolism in a dual-flow continuous culture system

\begin{tabular}{lcccrrr}
\hline & \multicolumn{3}{c}{ Treatment $^{1}$} & & \\
\cline { 2 - 4 } Item & CON & WBD & LPSD & SEM & $P$-value \\
\hline $\mathrm{NH}_{3}-\mathrm{N}, \mathrm{mg} / 100 \mathrm{~mL}$ & $13.7^{\mathrm{a}}$ & $6.40^{\mathrm{b}}$ & $13.6^{\mathrm{a}}$ & 0.62 & $<0.01$ \\
$\mathrm{~N} \mathrm{flow,} \mathrm{g/d}$ & & & & & \\
Total N & 1.92 & 1.86 & 1.90 & 0.03 & 0.39 \\
$\mathrm{NH}_{3}-\mathrm{N}^{2}$ & $0.37^{\mathrm{a}}$ & $0.17^{\mathrm{b}}$ & $0.37^{\mathrm{a}}$ & 0.02 & $<0.01$ \\
$\mathrm{NAN}^{3}$ & $1.55^{\mathrm{b}}$ & $1.69^{\mathrm{a}}$ & $1.53^{\mathrm{b}}$ & 0.05 & 0.04 \\
Bacterial-N $^{4}$ & $0.82^{\mathrm{a}}$ & $0.80^{\mathrm{a}}$ & $0.69^{\mathrm{b}}$ & 0.03 & 0.04 \\
Dietary N $^{5}$ & 0.73 & 0.89 & 0.83 & 0.05 & 0.09 \\
Bacterial efficiency $^{6}$ & 21.0 & 20.0 & 18.5 & 1.00 & 0.24 \\
\hline
\end{tabular}

${ }^{\mathrm{a}, \mathrm{b}}$ Least squares means within the same row with different superscripts differ $(P<0.05)$.

${ }^{1} \mathrm{CON}=$ control diet; $\mathrm{WBD}=$ wheat and barley diet inducing SARA; LPSD $=$ control diet + LPS.

${ }^{2} \mathrm{NH}_{3}-\mathrm{N}(\mathrm{g} / \mathrm{d})=\mathrm{mg} / \mathrm{dL}$ of effluent $\mathrm{NH}_{3}-\mathrm{N} \times(\mathrm{g}$ of total effluent flow/100).

${ }^{3} \mathrm{NAN}=$ nonammonia $\mathrm{N}$. It was calculated as follows: NAN flow $(\mathrm{g} / \mathrm{d})$ $=\mathrm{g}$ of effluent $\mathrm{N}-\mathrm{g}$ of effluent $\mathrm{NH}_{3}-\mathrm{N}$.

${ }^{4}$ Bacterial-N flow was calculated according to Calsamiglia et al. (1996), using the following equation: bacterial $\mathrm{N}$ flow $(\mathrm{g} / \mathrm{d})=(\mathrm{NAN}$ flow $\times$ atom percentage excess of ${ }^{15} \mathrm{~N}$ of effluent)/(atom percentage excess of ${ }^{15} \mathrm{~N}$ of bacteria).

${ }^{5}$ Dietary $\mathrm{N}$ flow $(\mathrm{g} / \mathrm{d})=\mathrm{g}$ of effluent NAN $-\mathrm{g}$ of effluent bacterial $\mathrm{N}$. ${ }^{6}$ Bacterial efficiency was calculated according to Calsamiglia et al. (1996) using the following equation: bacterial efficiency $=\mathrm{g}$ of bacterial $\mathrm{N}$ flow/kg of $\mathrm{OM}$ truly digested. rochaetaceae had the highest relative abundance across the treatments: 36,16 , and $6 \%$ of total sequences, respectively. A total of 139 genera were identified, with Prevotella as the predominant genus, representing $36 \%$ of the relative abundance across the treatments. The genera Treponema, Succiniclasticum, Coprococcus, and Ruminobacter represented 5.4, 3.1, 3.0, and $2.4 \%$ of the total sequences across the treatments, respectively.

\section{Bacterial Community Composition}

In both of liquid and solid fractions, no interactions were observed between treatments and time on BCC (Supplemental Table S1; https://doi.org/10.3168/jds .2018-14807). In the solid fraction, the BCC of LPSD was different from WBD in both composition and structure (composition and abundance of BCC) and tended to be different from CON $(P=0.09$, Figure 7A, Supplemental Table S2; https://doi.org/10.3168/ jds.2018-14807). In the liquid fraction, the composition and structure of BCC were different among treatments (Figure 7B, Supplemental Table S2; https://doi.org/ 10.3168/jds.2018-14807). There was no interaction between treatments and time on richness and diversity in both solid and liquid fractions. In both solid and liquid fractions, LPS dosing had no effect on the richness and diversity of bacteria, and the lowest richness and diversity among treatments were observed in WBD (Figure 8).

Treatment effects on the relative abundance of phylum are presented in Supplemental Table S3 (https: 

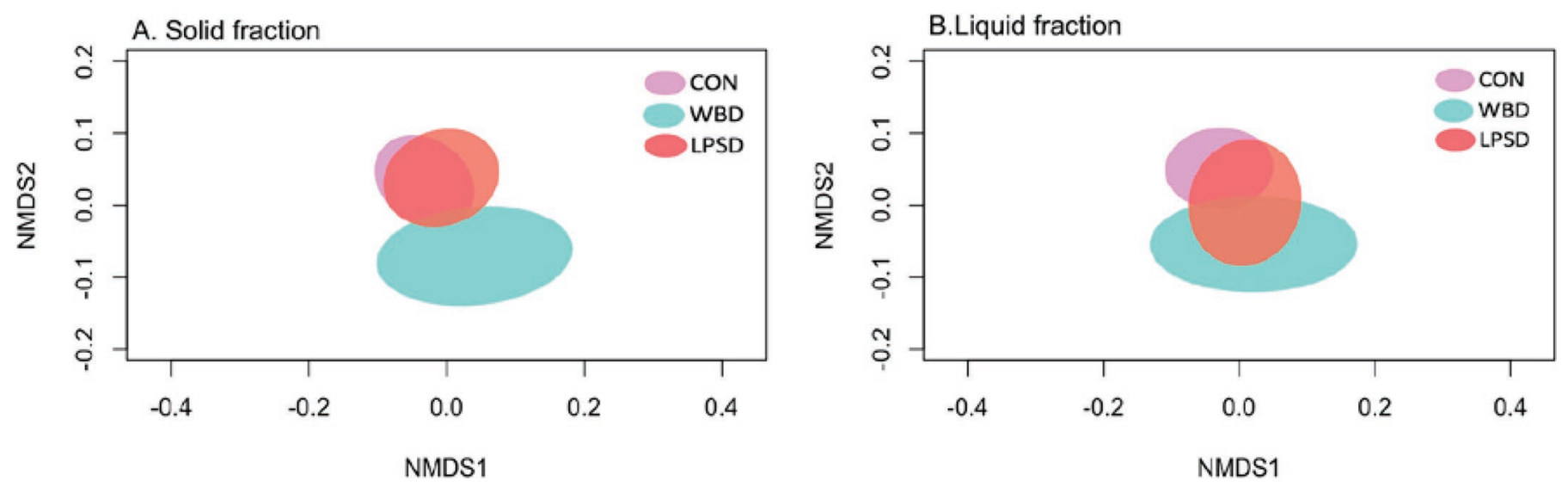

Figure 7. Nonmetric multidimensional scaling (NMDS) plots of the Bray-Curtis similarity index comparing the bacterial community composition of treatments in a dual-flow continuous culture system. $\mathrm{CON}=$ control diet; WBD $=$ wheat and barley diet inducing SARA; LPSD $=$ control diet + LPS. Ellipses represent 95\% CI.

//doi.org/10.3168/jds.2018-14807). In both solid and liquid fractions, LPS dosing increased the relative abundance of Tenericutes and SR1 when compared with CON. The lowest relative abundance of Firmicutes and the highest relative abundance of Bacteroidetes were observed in WBD, but no difference was observed between LPSD and CON.

The effects of treatments on relative abundance of genera are presented in Supplemental Table S4 (https: //doi.org/10.3168/jds.2018-14807). Compared with CON, LPS dosing increased the relative abundance of Succinimonas, Anaeroplasma, and Succinivibrio in both liquid and solid fractions, and increased the relative abundance of Succiniclasticum and BF311 whereas it decreased the relative abundance of Coprococcus in the solid fraction. The relative abundance of Succinimonas was not different between LPSD and WBD in both liquid and solid fractions, as well as Succinivibrio and Coprococcus in the solid fraction. The highest relative abundance of Prevotella was observed in WBD.

Based on the relative abundance of top 100 OTU in the solid fraction, compared with CON, LPS dosing increased the relative abundance of Lachnospiraceae (Butyrivibrio), Succinivibrionaceae (Ruminobacter and Succinivibrio), Anaeroplasmataceae (Anaeroplasma), Veillonellaceae (Succiniclasticum), and Paraprevotellaceae (YRC22), whereas it decreased the relative abundance of Spirochaetaceae (Treponema) and Provotella ruminicola. The relative abundance of some Prevotella was not different between LPSD and WBD and higher than the CON; the relative abundance of Ruminococceceae (Oscillospira and Ruminococcus) was not different between LPSD and WBD but lower than the CON (Figure 9). In the liquid fraction, compared with CON, LPS dosing increased the relative abundance of Anaeroplasmataceae (Anaeroplasma), Spirochaeta- ceae (Treponema), Succinivibrionaceae (Succinivibrio), RF16 (unclassified), and Paraprevotellaceae (YRC22), whereas it decreased the relative abundance of some Prevotella. The relative abundance of Veillonellaceae (Succiniclasticum) and some Prevotella was not different between LPSD and WBD and higher than the $\mathrm{CON}$; the relative abundance of Prevotella ruminicola was not different between LPSD and WBD but was lower than the CON (Figure 10).

\section{DISCUSSION}

The current definition of SARA is based on the $\mathrm{pH}$ of the rumen fluid. An episode of ruminal $\mathrm{pH}$ between 5.2 to 5.6 for more than $180 \mathrm{~min} / \mathrm{d}$ is used as a threshold for SARA (Kleen et al., 2003; Stone, 2004; Gozho et al., 2005). In our study, $40 \%$ of DM of CON was replaced by equal proportion of ground wheat and barley (50:50) to induce SARA in a dual-flow continuous culture system. Based on the $\mathrm{pH}$ results, WBD successfully kept $\mathrm{pH}$ between 5.2 to 5.6 for $4 \mathrm{~h} / \mathrm{d}(240 \mathrm{~min} / \mathrm{d})$, which was in agreement with 279 and $506 \mathrm{~min} / \mathrm{d}$ reported by Khafipour et al. (2009b) and Krause and Oetzel (2005) that induced SARA by wheat and barley, respectively. Meanwhile, concentration of LPS was 11-fold higher than CON, which was similar to cows with SARA, where concentration of LPS ranged from 4 to 16-fold higher compared with cows without SARA (Gozho et al., 2007; Khafipour et al., 2009a; Li et al., 2012). Therefore, a SARA nutritional model was successfully established in the dual-flow continuous culture system and WBD can be used as a positive control to evaluate how LPS dosing contributes to SARA pathogenesis.

The $\mathrm{pH}$ of CON was higher than 6 for the entire experimental period in our study, which met our expectation and could be served as a negative control (no 
SARA). Because the $\mathrm{pH}$ in $\mathrm{CON}$ was higher than 6 and LPS concentration was low $(<3,000 \mathrm{EU} / \mathrm{mL})$, which indicates that the control diet did not induce SARA and would not interfere with LPS dosing treatment. Therefore, when LPS was added in LPSD, the increase of LPS concentration in LPSD compared with CON (6,712 vs. $1,898 \mathrm{EU} / \mathrm{mL}$ ) was due to effects of LPS dosing and not due to the experimental diet. The $\mathrm{pH}$ pattern of LPSD was similar to CON, which was higher than 6. Therefore, LPS dosing had no direct effect on $\mathrm{pH}$. This is against our hypothesis that LPS dosing would decrease $\mathrm{pH}$. Therefore, in our study, LPS could not directly affect $\mathrm{pH}$ through changes in bacteria and bacterial fermentation.

Reduction in $\mathrm{pH}$ below 5.6 have significant effects on microbial activity and rumen function (Nagaraja and Titgemeyer, 2007). Grain-induced SARA reduced ruminal fiber digestibility (Krajcarski-Hunt et al., 2002; Plaizier et al., 2008) due to a reduction in the ability of cellulolytic bacteria to attach to feed particle (Cheng et al., 1980) or the slow replication rate of cellulolytic bacteria under low pH (Russell and Dombrowski, 1980), or both. Cellulolytic bacteria generally cannot tolerate a rumen pH below 6.0 (Shi and Weimer, 1992). The reduction in fiber digestion in WBD was mirrored with the reduction in the relative abundance of cellulolytic bacteria (genera Fibrobacter, Ruminococcus,
Butyrivibrio, and Clostridium). The $\mathrm{pH}$ of LPSD was between 6 and 7.2, which was optimal for cellulolytic bacterial growth (Russell, 2002). Therefore, the main cellulolytic bacteria (genera Fibrobacter, Ruminococcus, Butyrivibrio, and Clostridium) were not depressed by LPS dosing in the present study. However, fiber digestion in LPSD was not different from WBD, which indicates that other factors besides $\mathrm{pH}$ may play a role in fiber digestion.

The decrease in cellulolytic bacteria contributed to a decrease in the molar proportion of acetate in WBD, as acetate is the main end product of these bacteria fermentation (Russell, 2002). Also, a decrease of acetate: propionate ratio was also observed in WBD. This is generally observed when animals are switched from a high-forage to a high-grain diet or in a grain-induced SARA (Plaizier et al., 2012, 2017). Molar proportion of acetate and propionate in LPSD was not different from $\mathrm{CON}$, and thus no difference was present in acetate to propionate ratio between LPSD and CON as well. Fiber digestion was decreased in LPSD, whereas no effects were observed of LPS on concentration of acetate, indicating that acetate is not the only fermentation end product coming from cellulolytic bacteria. Other bacteria, such as starch utilizer genera Succinivibrio and $R u$ minobacter, have been reported to produce acetate as well (Russell, 2002). In the present study, the BCC was
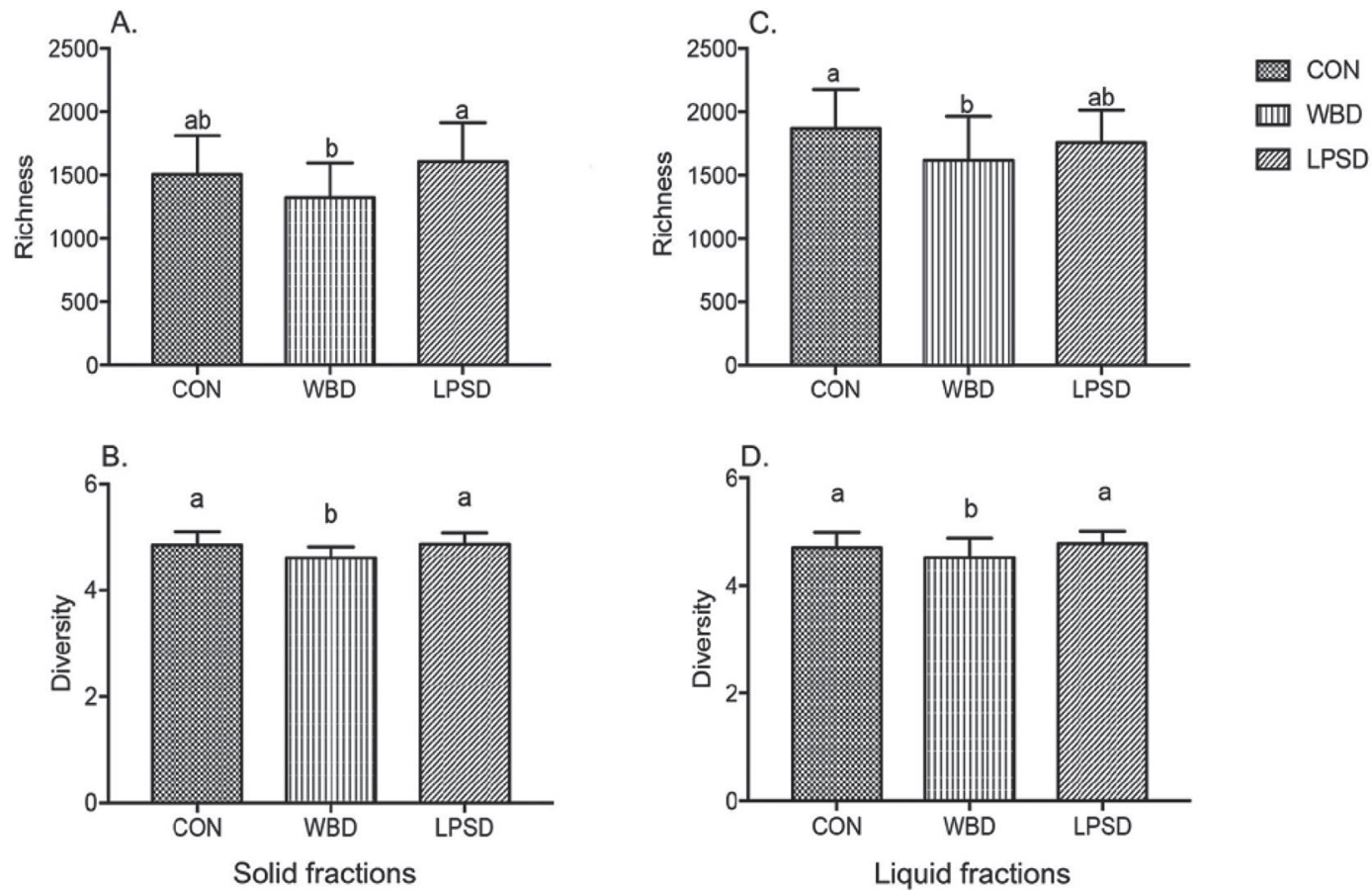

Figure 8. Effects of LPS on the richness (A and C) and diversity (B and D) of bacteria in both solid and liquid fractions in a dual-flow continuous culture system. $\mathrm{CON}=$ control diet; $\mathrm{WBD}=$ wheat and barley diet inducing SARA; LPSD $=$ control diet + LPS. Richness was calculated based on Chao 1 index; diversity was calculated based on Invsimpson index. Different letters (a,b) indicate a significant difference between treatments $(P \leq 0.05)$. 

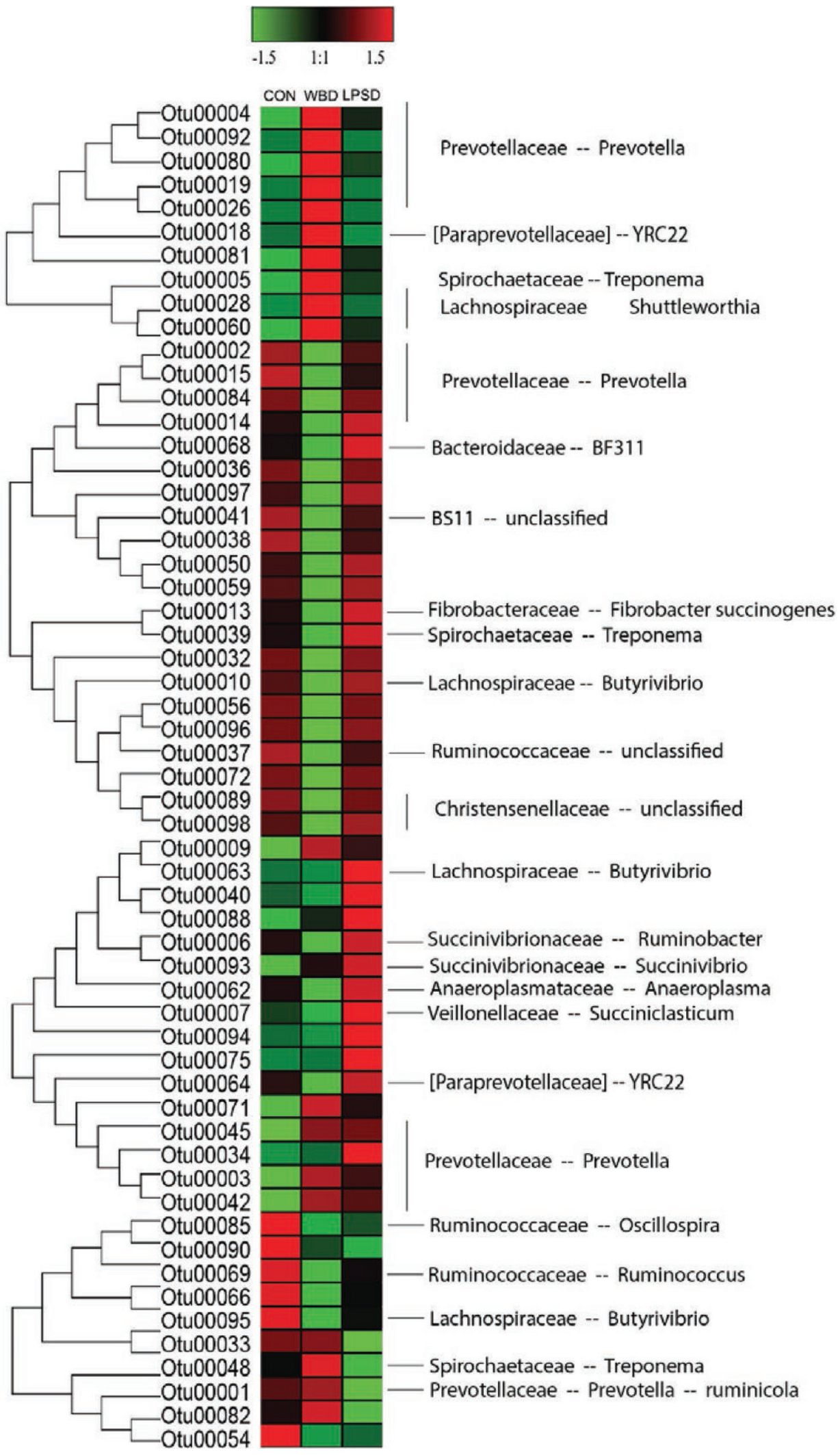

Figure 9. Effects of LPS on the relative abundance of top-100 operational taxonomic units (OTU) in the solid fraction in a dual-flow continuous culture system. The evolutionary history was inferred by using the maximum likelihood method based on the Tamura-Nei model. CON $=$ control diet; $\mathrm{WBD}=$ wheat and barley diet inducing SARA; LPSD $=$ control diet + LPS. 


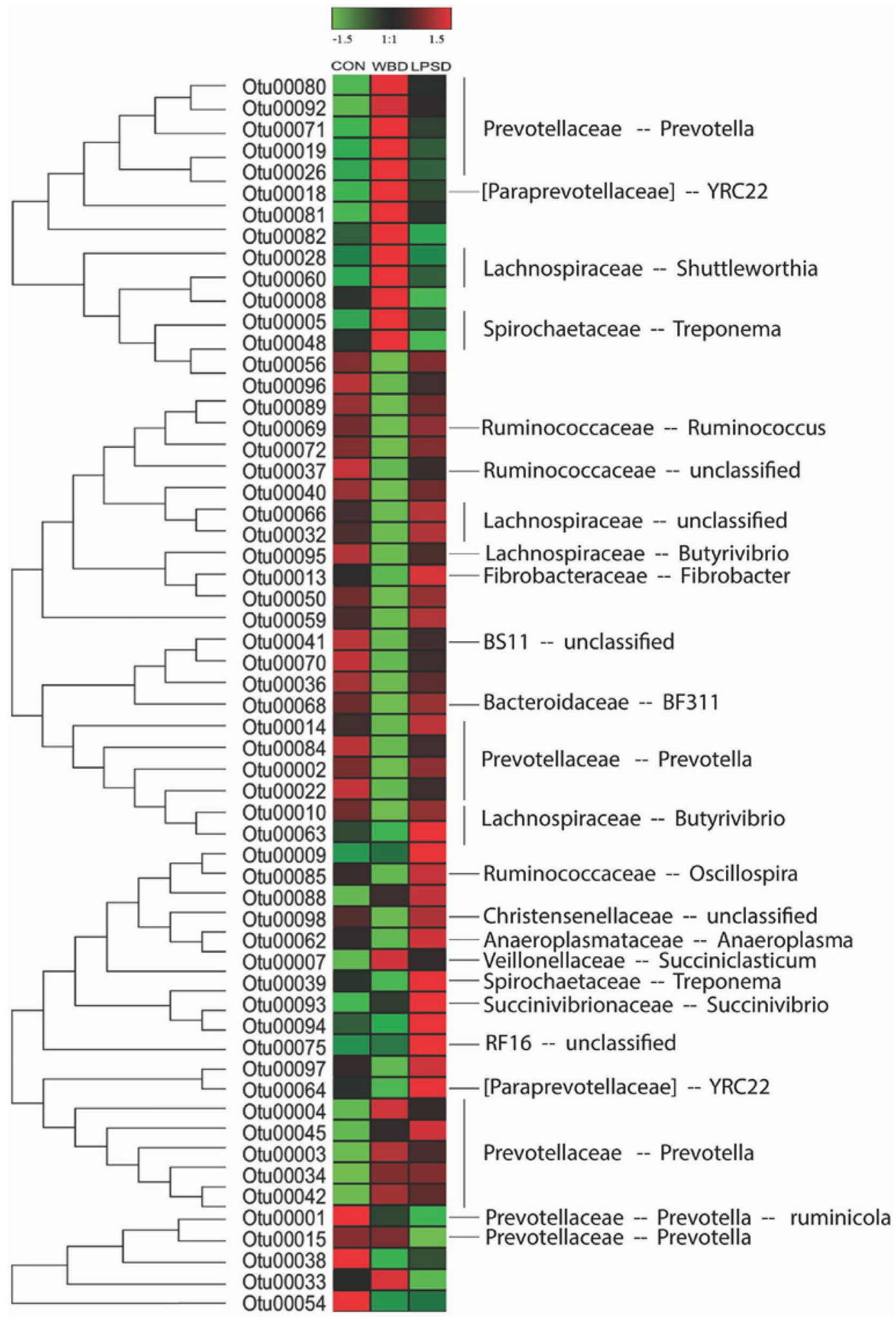

Figure 10. Effects of LPS on the relative abundance of top-100 operational taxonomic units (OTU) in the liquid fraction in a dual-flow continuous culture system. The evolutionary history was inferred by using the maximum likelihood method based on the Tamura-Nei model. $\mathrm{CON}=$ control diet; WBD $=$ wheat and barley diet inducing SARA; LPSD = control diet + LPS. 
altered, and bacterial $\mathrm{N}$ was decreased by LPS dosing, but bacterial efficiency was not affected by LPS dosing.

The molar proportion of propionate was not different among treatments. Instead, the molar proportion of butyrate was increased in WBD, showing a shift from propionate to butyrate in WBD. Marounek et al. (1989) have found that in the presence of glucose, there was an increase in the production of butyrate with a concurrent reduction in propionate. Other studies also showed that animals with experimentally induced acidosis with an intraruminal starch challenge had greater butyrate concentrations (Nagaraja et al., 1985; Coe et al., 1999). Therefore, the higher dietary starch content in WBD (31\% DM) could have driven the propionate to butyrate and thus increased the molar proportion of butyrate in WBD.

Rumen $\mathrm{pH}$ is known to drop when organic acids, such as VFA and lactic acid, accumulate in the rumen, and when ruminal buffering cannot keep pace with the accumulation of these acids (Plaizier et al., 2008). Total VFA concentration was not different among treatments, which could be partially explained by the lack of treatment effects on DM and OM digestibility. Therefore, the decrease in $\mathrm{pH}$ in WBD could contribute to an increase in lactate concentration in WBD, which was 4 times higher than CON (1.07 vs. $0.25 \mathrm{mM}$ ). However, the lactate concentration of WBD was still within typical lactate concentration observed when SARA occurs (0 to $5 \mathrm{~m} M$, Nagaraja et al., 1998), indicating that, in our study, SARA was not related to lactate.

In the present study, a tendency to decrease $\mathrm{CP}$ digestions was found in WBD when compared with CON. Calsamiglia et al. (2002) also observed a decrease in protein degradation in constant low $\mathrm{pH}(5.7)$ compared with high $\mathrm{pH}$ (6.4). Tendency to reduce protein degradation is supported by a tendency to reduction isobutyrate concentration in WBD. Low $\mathrm{pH}$ (5.7) had been shown to increase NAN and dietary $\mathrm{N}$ flow but decrease $\mathrm{NH}_{3}-\mathrm{N}$ flow compared with constant high $\mathrm{pH}$ (6.4) in a dual-flow continuous culture system, but the bacterial $\mathrm{N}$ flow and bacteria efficiency were not different between low and high $\mathrm{pH}$ (Calsamiglia et al., 2002), which was consistent with the present study. The decreased $\mathrm{NH}_{3}-\mathrm{N}$ concentration found in WBD could be due to lower dietary $\mathrm{CP}$ (14.8\% in WBD). Ruminal ammonia concentration is an indicator of protein degradation (Broderick and Kang, 1980). Less $\mathrm{NH}_{3}-\mathrm{N}$ in WBD when compared with $\mathrm{CON}$ was also consistent with a lower $\mathrm{CP}$ degradation. The change in fiber and $\mathrm{CP}$ digestion and the concentration of VFA in WBD, together with no changes in the total production of bacterial $\mathrm{N}$, suggest that diets were able to maintain the same bacterial growth inside the fermentors.
The LPS dosing in the rumen also tended to have lower CP digestion (45.0 vs. $50.8 \%$, respectively) compared with CON. It is likely that the reduced protein degradation may be related to the reduction in the digestibility of fiber associated with the protein within feeds. The undigested fiber within feed could reduce the access of bacteria and enzymes to the protein and therefore reduce protein degradation (Wallace and Cotta, 1989; Devant et al., 2000). Jing et al. (2014) also found that protein and fiber digestibility of soybean meal linearly decreased with intravenous LPS infusion. Meanwhile, a lower relative abundance of OTU0001 (average of $12.3 \%$ of total sequence, Prevotella ruminicola) was observed in both LPSD and WBD compared with CON in the liquid fraction. These bacteria are believed to play an important role in the degradation of proteins and in the uptake and fermentation of peptides (Stewart and Flint, 1992; Russell, 2002), and thus decrease of this bacterium could contribute to the decrease of CP degradation in both LPSD and WBD. Finally, reduction of bacterial $\mathrm{N}$ in LPSD compared with CON (0.69 vs. $0.82 \mathrm{~g} / \mathrm{d}$ ) could also contribute to the lower $\mathrm{CP}$ digestion.

Dosing of LPS had no effect on the concentration of pooled total VFA and individual VFA; however, $6 \mathrm{~h}$ after LPS dosing ( $8 \mathrm{~h}$ after morning feeding), patterns of VFA in LPSD started to be similar to WBD. This suggests that it takes at least $6 \mathrm{~h}$ for LPS to start affecting bacterial fermentation. Pattern of LPS concentration in both LPSD and WBD also started to be similar $6 \mathrm{~h}$ after LPS/WB dosing. Therefore, to study the effect of LPS dosing $(200,000 \mathrm{EU} / \mathrm{mL})$ on bacterial fermentation, samples are suggested to be taken at least $6 \mathrm{~h}$ after the first LPS dosing ( $8 \mathrm{~h}$ after morning feeding).

Similar patterns and concentration of VFA between LPSD and WBD $8 \mathrm{~h}$ after morning feeding $(6 \mathrm{~h}$ after LPS dosing), together with no difference in fiber and CP degradation between LPSD and WBD, and decrease of bacterial $\mathrm{N}$, and change of BCC by LPS dosing, suggests that LPS could have effects on bacteria and bacterial fermentation and these effects could drive the development of SARA.

Two hours after the first LPS dosing ( $4 \mathrm{~h}$ after morning feeding), concentration of LPS decreased to 3,000 $\mathrm{EU} / \mathrm{mL}$ and $6 \mathrm{~h}$ after LPS dosing (time point when LPS started to affect bacterial fermentation), LPS in LPSD increased to similar concentration as WBD and similar VFA patterns and concentration were found between LPSD and WBD. Pools of LPS concentration in LPSD were around 3-fold lower than WBD (6,712 vs. $20,770 \mathrm{EU} / \mathrm{mL}$ ). This may explain the lack of effects of LPS dosing on pool of VFA concentrations.

The concentration of total and individual VFA in LPSD and WBD started to increase $6 \mathrm{~h}$ after LPS 
dosing ( $8 \mathrm{~h}$ after morning feeding), and this was similar to the diurnal pattern of LPS concentration in LPSD and WBD where LPS concentration started to increase again $6 \mathrm{~h}$ after LPS dosing. Therefore, increase of VFA $6 \mathrm{~h}$ after LPS dosing $(8 \mathrm{~h}$ after morning feeding) could be due to increase in LPS either by dosing or because of SARA. Lipopolysaccharide that consists of O-polysaccharide chain, an R-core, and lipid A moiety (Guerville and Boudry, 2016), which may be degraded by bacteria and used as substrate for bacterial fermentation, contributing to the increase in fermentation end products such as VFA. Lipopolysaccharide has been reported to stimulate the growth of gram-negative ruminal Mycoplasma in the pure culture (Robinson and Hungate, 1973; Robinson et al., 1975). Pool and diurnal concentration of LPS in LPSD was lower than dosing concentration $(200,000 \mathrm{EU} / \mathrm{mL})$, indicating a degradation of LPS in the fermentor, supporting that LPS could be degraded and used as substrate for bacteria.

Pool LPS concentration in WBD was around 11-fold higher than CON, and in LPSD it was around 4 fold higher than CON. Increase of LPS concentration in SARA was also found in several studies (Gozho et al., 2005; Khafipour et al., 2009a; Plaizier et al., 2017). Proportion of gram-negative bacteria in the rumen decreases when $\mathrm{pH}$ decreases; therefore, some studies suggest that LPS in the rumen comes from either intact rapidly growing gram-negative bacteria, or from gram-negative bacterial death and lysis (Nagaraja et al., 1978b). It has been reported that as much as $60 \%$ of LPS in the rumen may be released during bacterial growth (Andersen, 2000). During rapid growth, expanding and growing of bacteria requires autolytic enzymes, but excessive autolytic activity could lead to bacterial cell lysis (Khafipour et al., 2009a). Therefore, it is possible that low $\mathrm{pH}$ conditions causing lysis of gram-negative bacteria and rapidly fermented substrate causing rapidly gram-negative bacterial growth could contribute to increases of LPS in WBD. When we dosed LPS in the fermentors, concentration of LPS decreased first to a low level and then increased again $8 \mathrm{~h}$ after morning feeding. Increase LPS concertation could be due to LPS render rapidly growth of some bacteria and thus increase LPS concentration. Compared with CON, the BCC was affected by LPS dosing. Intravenous LPS challenge have been reported to alter ruminal bacterial microbiota in lactating cows, but this was mainly attributed to alternations in ruminal $\mathrm{pH}$ (Jing et al., 2014). In the present study, the $\mathrm{pH}$ was not changed by LPS dosing. Therefore, the shift in BCC by LPS dosing in the present study suggests that LPS is capable of changing $\mathrm{BCC}$ independent of $\mathrm{pH}$; bacterial $\mathrm{N}$ was also found to be decreased by LPS dosing.
The LPS dosing increased the relative abundance of Succinimonas, Anaeroplasma, Succinivibrio, Succiniclasticum, and Ruminobacter (OTU00006, 2.4\% of total sequence) in LPSD. Succinimonas (Succinimonas amylolytica), gram-negative straight rods, is normally associated with starch digestion (Williams et al., 1984); Succinivibrio (Succinivibrio dextrinosolvens), a gramnegative bacterium, is also associated with starch digestion, with some strains possessing enzymes that could enable products of plant cell wall breakdown to be used (Williams et al., 1984). Anaeroplasma belongs to order Mycoplasma and is a gram-negative bacterium. Anaeroplasma bactoclasticum could digest bacteria (Stewart et al., 1997), and all strains grow in medium with soluble starch (Robinson et al., 1975). Succiniclasticum (Succiniclasticum ruminis) is a gram-negative bacterium that ferments succinate to propionate, and succinate is the main fermented product of starch digestion (Russell, 2002). Ruminobacter (Ruminobacter amylophilus) is a gram-negative bacteria and predominant starch digester (Holdeman et al., 1984). Therefore, LPS dosing mainly shifted BCC to have more gram-negative bacterial associated with starch digestion. This is in agreement with a $2.5 \%$ numerically higher starch digestion observed in LPSD compared with CON. Increased growth of these gram-negative bacteria could in turn increase LPS concentration in LPSD due to excessive autolytic activity as stated before. Increased amylolytic bacteria was generally found in cows with SARA challenge (Fernando et al., 2010; Mao et al., 2013; Plaizier et al., 2017). Therefore, increase of these bacteria by LPS may also indicate a potential role of LPS in the development of SARA.

\section{CONCLUSIONS}

In conclusion, LPS dosing did not directly affect $\mathrm{pH}$ through changes in bacteria and bacterial fermentation. Digestibility of fiber and $\mathrm{CP}$ were not different between LPSD and WBD but tended to be lower than CON. The LPS dosing had no effects on pools of VFA concentration but decreased bacterial N. Daily patterns of VFA and LPS concentration in LPSD started to be similar to WBD and increased $6 \mathrm{~h}$ after the first LPS dosing, suggesting that future studies with LPS should last for at least $6 \mathrm{~h}$ after LPS dosing. Lipopolysaccharide dosing changed BCC, especially in the liquid fraction, mainly through stimulation of gram-negative bacteria associated with starch digestion. Furthermore, the $\mathrm{pH}$ of WBD stayed between 5.2 and 5.6 for $4 \mathrm{~h} / \mathrm{d}$ and LPS concentration was 11-fold higher than CON; therefore, inclusion of $40 \%$ (DM basis) of a wheat and barley mixture can successfully induce SARA in a dualflow continuous culture system. 


\section{ACKNOWLEDGMENTS}

The authors acknowledge Teshome Shenkoru (University of Nevada, Reno) for help and technical support during the entire experiment. We also thank Timothy Hackmann (University of Florida) for assistance with lactate analysis, Luiz Ferraretto, laboratory crew (University of Florida) for assistance with starch analysis, and the NextGen DNA sequencing laboratory, UFInterdisciplinary Center for Biotechnology Research at the University of Florida for performing the MiSeq sequencing runs and the Information Technology department at the University of Nevada, Reno, for computing time on the High-Performance Computing Cluster. We also acknowledge the farm crew at the Main Station Field Laboratory (University of Nevada-Reno) for animal feeding and care.

\section{REFERENCES}

Andersen, P. H. 2000. Endotoxicosis: Aspects of relevance to ruminal acidosis. Dr. Vet. Sci. Thesis. The Royal Veterinary and Agricultural University, Copenhagen, Denmark.

Anderson, P. H., B. Bergelin, and K. A. Christensen. 1994. Effect of feeding regimen on concentration of free endotoxin in ruminal fluid of cattle. J. Anim. Sci. 72:487-491.

AOAC (Association of Official Analytical Chemists). 1990. Official Methods of Analysis. 15th ed. AOAC, Arlington, VA.

AOAC International. 2005. Official Methods of Analysis. 18th ed. AOAC International, Arlington, VA.

Brandao, V. L. N., X. Dai, E. M. Paula, L. G. Silva, M. I. Marcondes, T. Shenkoru, S. Poulson, and A. P. Faciola. 2018. Effect of replacing calcium salts of palm oil with camelina seed at two dietary ether extract levels on digestion, ruminal fermentation and nutrient flow in a dual-flow continuous culture system. J. Dairy Sci. 101:5046-5059.

Britton, R., and R. Stock. 1989. Acidosis: A continual problem in cattle fed high grain diets. Pages 8-15 in Proc. Cornell Nutr. Conf. Feed Manuf., Cornell Univ., Ithaca, NY.

Broderick, G. A., and J. H. Kang. 1980. Automated simultaneous determination of ammonia and total amino acids in ruminal fluid and in vitro media1. J. Dairy Sci. 63:64-75. https://doi.org/10 $.3168 /$ jds.S0022-0302(80)82888-8.

Calsamiglia, S., A. Ferret, and M. Devant. 2002. Effects of pH and $\mathrm{pH}$ fluctuations on microbial fermentation and nutrient flow from a dual-flow continuous culture system. J. Dairy Sci. 85:574-579. https://doi.org/10.3168/jds.S0022-0302(02)74111-8.

Calsamiglia, S., M. D. Stern, and J. L. Firkins. 1996. Comparison of nitrogen-15 and purines as microbial markers in continuous culture. J. Anim. Sci. 74:1375-1381.

Chaney, A. L., and E. P. Marbach. 1962. Modified reagents for determination of urea and ammonia. Clin. Chem. 8:130 LP-132.

Cheng, K. J., J. Fay, and R. Howarth. 1980. Sequence of events in the digestion of fresh legume leaves by rumen bacteria. Appl. Environ. Microbiol. 40:613-625.

Coe, M. L., T. G. Nagaraja, Y. D. Sun, N. Wallace, E. G. Towne, K. E. Kemp, and J. P. Hutcheson. 1999. Effect of virginiamycin on ruminal fermentation in cattle during adaptation to a high concentrate diet and during an induced acidosis. J. Anim. Sci. 77:2259-2268.

Dai, X., P. J. Weimer, K. A. Dill-McFarland, V. L. N. Brandao, G. Suen, and A. P. Faciola. 2017. Camelina seed supplementation at two sietary fat levels change ruminal bacterial community composition in a dual-flow continuous culture system. Front. Microbiol. 8:2147. https://doi.org/10.3389/fmicb.2017.02147.
Desantis, T. Z., P. Hugenholtz, N. Larsen, M. Rojas, E. L. Brodie, K. Keller, T. Huber, D. Dalevi, P. Hu, and G. L. Andersen. 2006. Greengenes, a chimera-checked $16 \mathrm{~S}$ rRNA gene database and workbench compatible with ARB. Appl. Environ. Microbiol. 72:5069-5072. https://doi.org/10.1128/AEM.03006-05.

Devant, M., A. Ferret, S. Calsamiglia, R. Casals, and J. Gasa. 2000. Effects of protein concentration and degradability on performance, ruminal fermentation, and nitrogen metabolism in rapidly growing heifers fed high-concentrate diets from 100 to $230 \mathrm{~kg}$ body weight. J. Anim. Sci. 78:1667-1676.

Dougherty, R. W. 1976. Physiological changes in ruminants being fed high energy feeds. Pages 49-60 in Buffers in Ruminant Physiology and Metabolism. M. S. Weinberg and A. L. Sheffner, ed. Church and Dwight Co., New York, NY.

Dunlop, R. H. 1972. Pathogenesis of ruminant lactic acidosis. Adv. Vet. Sci. Comp. Med. 16:259-302.

Fernando, S. C., H. T. Purvis, F. Z. Najar, L. O. Sukharnikov, C. R. Krehbiel, T. G. Nagaraja, B. A. Roe, and U. De Silva. 2010. Rumen microbial population dynamics during adaptation to a highgrain diet. Appl. Environ. Microbiol. 76:7482-7490. https://doi .org/10.1128/AEM.00388-10.

Gozho, G. N., D. O. Krause, and J. C. Plaizier. 2006. Rumen lipopolysaccharide and inflammation during grain adaptation and subacute ruminal acidosis in steers. J. Dairy Sci. 89:4404-4413. https://doi.org/10.3168/jds.S0022-0302(06)72487-0.

Gozho, G. N., D. O. Krause, and J. C. Plaizier. 2007. Ruminal lipopolysaccharide concentration and inflammatory response during grain-induced subacute ruminal acidosis in dairy cows. J. Dairy Sci. 90:856-866. https://doi.org/10.3168/jds.S0022-0302(07)71569 -2 .

Gozho, G. N., J. C. Plaizier, D. O. Krause, A. D. Kennedy, and K. M. Wittenberg. 2005. Subacute ruminal acidosis induces ruminal lipopolysaccharide endotoxin release and triggers an inflammatory response. J. Dairy Sci. 88:1399-1403. https://doi.org/10.3168/jds .S0022-0302(05)72807-1.

Guerville, M., and G. Boudry. 2016. Gastrointestinal and hepatic mechanisms limiting entry and dissemination of lipopolysaccharide into the systemic circulation. Am. J. Physiol. Gastrointest. Liver Physiol. 311:G1-G15. https://doi.org/10.1152/ajpgi.00098.2016.

Hall, M. B., J. Arbaugh, K. Binkerd, A. Carlson, T. Thi Doan, T. Grant, C. Heuer, H. D. Inerowicz, B. Jean-Louis, R. Johnson, J. Jordan, D. Kondratko, E. Maciel, K. McCallum, D. Meyer, C. A. Odijk, A. Parganlija-Ramic, T. Potts, L. Ruiz, S. Snodgrass, D. Taysom, S. Trupia, B. Steinlicht, and D. Welch. 2015. Determination of dietary starch in animal feeds and pet food by an enzymatic-colorimetric method: Collaborative study. J. AOAC Int. 98:397-409. https://doi.org/10.5740/jaoacint.15-012.

Henderson, G., F. Cox, S. Kittelmann, V. H. Miri, M. Zethof, and S. J. Noel. 2013. Effect of DNA extraction methods and sampling techniques on the apparent structure of cow and sheep rumen microbial communities. PLoS One 8:e74787. https://doi.org/10.1371/ journal.pone.0074787.

Holdeman, L. V., R. W. Kelley, and W. E. C. Moore. 1984. Bacteroides. Pages 604-631 in Bergey's Manual of Systematic Bacteriology. Vol. 1. N. R. Krieg and J. G Holt, ed. Williams \& Willkins, Baltimore, MD.

Hoover, W. H., P. H. Knowlton, M. D. Stern, and C. J. Sniffen. 1976. Effects of differential solid-liquid removal rates on fermentation parameters in continuous cultures of rumen contents. J. Anim. Sci. 43:535-542.

Huber, T. L. 1976. Physiological effects of acidosis on feedlot cattle. J. Anim. Sci. 43:902-909.

Jing, L., R. Zhang, Y. Liu, W. Zhu, and S. Mao. 2014. Intravenous lipopolysaccharide challenge alters ruminal bacterial microbiota and disrupts ruminal metabolism in dairy cattle. Br. J. Nutr. https:// doi.org/10.1017/S000711451400066X.

Keunen, J. E., J. C. Plaizier, L. Kyriazakis, T. F. Duffield, T. M. Widowski, M. I. Lindinger, and B. W. McBride. 2002. Effects of a subacute ruminal acidosis model on the diet selection of dairy cows. J. Dairy Sci. 85:3304-3313. https://doi.org/10.3168/jds .S0022-0302(02)74419-6. 
Khafipour, E., D. O. Krause, and J. C. Plaizier. 2009a. A grain-based subacute ruminal acidosis challenge causes translocation of lipopolysaccharide and triggers inflammation. J. Dairy Sci. 92:1060 1070. https://doi.org/10.3168/jds.2008-1389.

Khafipour, E., D. O. Krause, and J. C. Plaizier. 2009b. Alfalfa pelletinduced subacute ruminal acidosis in dairy cows increases bacterial endotoxin in the rumen without causing inflammation. J. Dairy Sci. 92:1712-1724. https://doi.org/10.3168/jds.2008-1656.

Kleen, J. L., G. A. Hooijer, J. Rehage, and J. P. T. M. Noordhuizen. 2003. Subacute ruminal acidosis (SARA): A review. J. Vet. Med. A Physiol. Pathol. Clin. Med. 50:406-414.

Kleen, J. L., L. Upgang, and J. Rehage. 2013. Prevalence and consequences of subacute ruminal acidosis in German dairy herds. Acta Vet. Scand. https://doi.org/10.1186/1751-0147-55-48.

Kozich, J. J., S. L. Westcott, N. T. Baxter, S. K. Highlander, and P. D. Schloss. 2013. Development of a dual-index sequencing strategy and curation pipeline for analyzing amplicon sequence data on the miSeq Illumina sequencing platform. Appl. Environ. Microbiol. 79:5112-5120. https://doi.org/10.1128/AEM.01043-13.

Krajcarski-Hunt, H., J. C. Plaizier, J.-P. Walton, R. Spratt, and B. W. McBride. 2002. Short communication: Effect of subacute ruminal acidosis on in situ fiber digestion in lactating dairy cows. J. Dairy Sci. 85:570-573.

Krause, K. M., and G. R. Oetzel. 2005. Inducing subacute ruminal acidosis in lactating dairy cows. J. Dairy Sci. 88:3633-3639.

Krizsan, S. J., S. Ahvenjärvi, H. Volden, and G. A. Broderick. 2010. Estimation of rumen outflow in dairy cows fed grass silage-based diets by use of reticular sampling as an alternative to sampling from the omasal canal 1. J. Dairy Sci. 93:1138-1147. https://doi .org/10.3168/jds.2009-2661.

Li, S., E. Khafipour, D. O. Krause, A. Kroeker, J. C. RodriguezLecompte, G. N. Gozho, and J. C. Plaizier. 2012. Effects of subacute ruminal acidosis challenges on fermentation and endotoxins in the rumen and hindgut of dairy cows. J. Dairy Sci. 95:294-303. https://doi.org/10.3168/jds.2011-4447.

Mao, S. Y., R. Y. Zhang, D. S. Wang, and W. Y. Zhu. 2013. Impact of subacute ruminal acidosis (SARA) adaptation on rumen microbiota in dairy cattle using pyrosequencing. Anaerobe. https://doi .org/10.1016/j.anaerobe.2013.08.003.

Marounek, M., K. Fliegrova, and S. Bartos. 1989. Metabolism and some characteristics of ruminal strains of Megasphaera elsdenii. Appl. Environ. Microbiol. 55:1570-1573.

Nagaraja, T. G., T. B. Avery, S. J. Galitzer, and D. L. Harmon. 1985 Effect of ionophore antibiotics on experimentally induced lactic acidosis in cattle. Am. J. Vet. Res. 46:2444-2452.

Nagaraja, T. G., E. E. Bartley, L. R. Fina, and H. D. Anthony. 1978b. Relationship of rumen gram-negative bacteria and free endotoxin to lactic acidosis in cattle. J. Anim. Sci. 47:1329-1337.

Nagaraja, T. G., E. E. Bartley, L. R. Fina, H. D. Anthony, and R. M. Bechtle. 1978a. Evidence of endotoxins in the rumen bacteria of cattle fed hay or grain. J. Anim. Sci. 47:226-234.

Nagaraja, T. G., M. L. Galyean, and N. A. Cole. 1998. Nutrition and disease. Vet. Clin. North Am. Food Anim. Pract. 14:257-277.

Nagaraja, T. G., and E. C. Titgemeyer. 2007. Ruminal acidosis in beef cattle: The current microbiological and nutritional outlook. J. Dairy Sci. 90:E17-E38. https://doi.org/10.3168/jds.2006-478.

NRC. 2001. Nutrient Requirements of Dairy Cattle. 7th rev. ed. Natl. Acad. Sci., Washington, DC.

Oksanen, J., F. G. Blanchet, R. Kindt, P. Legendere, P. R. Minchin, R. B. O'Hara, G. L. Simpson, P. Solymos, M. H. H. Stevens, and H. Wagner. 2015. Vegan: Community Ecology Package. R Package Vegan, Version 2.2-1. http://cran.r-project.org.

Owens, F. N., D. S. Secrist, W. J. Hill, and D. R. Gill. 1998. Acidosis in cattle: A review. J. Anim. Sci. 76:275-286.

Paula, E. M., H. F. Monteiro, L. G. Silva, P. D. B. Benedeti, J. L. P. Daniel, T. Shenkoru, G. A. Broderick, and A. P. Faciola. 2017. Effects of replacing soybean meal with canola meal differing in rumen-undegradable protein content on ruminal fermentation and gas production kinetics using 2 in vitro systems. J. Dairy Sci. 100:5281-5292. https://doi.org/10.3168/jds.2016-12301.
Plaizier, J. C., E. Khafipour, S. Li, G. N. Gozho, and D. O. Krause 2012. Subacute ruminal acidosis (SARA), endotoxins and health consequences. Anim. Feed Sci. Technol. https://doi.org/10.1016/j .anifeedsci.2011.12.004.

Plaizier, J. C., D. O. Krause, G. N. Gozho, and B. W. McBride. 2008. Subacute ruminal acidosis in dairy cows: The physiological causes, incidence and consequences. Vet. J. 176:21-31. https://doi.org/10 $.1016 / j . t v j 1.2007 .12 .016$.

Plaizier, J. C., S. Li, H. M. Tun, and E. Khafipour. 2017. Nutritional models of experimentally-induced subacute ruminal acidosis (SARA) differ in their impact on rumen and hindgut bacterial communities in dairy cows. Front. Microbiol. 7:2128. https://doi .org/10.3389/fmicb.2016.02128.

Pruesse, E., C. Quast, K. Knittel, B. M. Fuchs, F. O. Glo, and W. Ludwig. 2007. SILVA: A comprehensive online resource for quality checked and aligned ribosomal RNA sequence data compatible with ARB. 35:7188-7196. https://doi.org/10.1093/nar/gkm864.

Robinson, I. M., M. J. Allison, and P. A. Hartman. 1975. Anaeroplasma abactoclasticum gen.nov., sp.nov.: An obligately anaerobic Mycoplasma from the rumen. Int. J. Syst. Bacteriol. 25:173-181. https://doi.org/10.1099/00207713-25-2-173.

Robinson, J. P., and R. E. Hungate. 1973. Acholeplasma bactoclasticum sp. n., an anaerobic Mycoplasma from the bovine rumen. Int. J. Syst. Bacteriol. 23:171-181.

Russell, J. B. 2002. Rumen Microbiology and Its Role in Ruminant Nutrition. James B. Russell Publishing, Ithaca, NY

Russell, J. B., and D. B. Dombrowski. 1980. Effect of pH on the efficiency of growth by pure cultures of rumen bacteria in continuous culture. Appl. Environ. Microbiol. 39:604-610.

Shi, Y., and P. J. Weimer. 1992. Response surface analysis of the effects of $\mathrm{pH}$ and dilution rate on Ruminococcus flavefaciens FD-1 in cellulose-fed continuous culture. Appl. Environ. Microbiol. $58: 2583-2591$

Silva, L. G., J. Bunkers, E. M. Paula, T. Shenkoru, Y. Yeh, B. Amorati, D. Holcombe, and A. P. Faciola. 2016. Effects of flaxseed and chia seed on ruminal fermentation, nutrient digestibility, and longchain fatty acid flow in a dual-flow continuous culture system. J. Anim. Sci. 94:1600-1609. https://doi.org/10.2527/jas.2015-9750.

Stevenson, D. M., and P. J. Weimer. 2007. Dominance of Prevotella and low abundance of classical ruminal bacterial species in the bovine rumen revealed by relative quantification real-time PCR. Appl. Microbiol. Biotechnol. 75:165-174. https://doi.org/10.1007/ s00253-006-0802-y.

Stewart, C. S., and H. J. Flint. 1992. The rumen bacteria. Pages 10-72 in The Rumen Microbial Ecosystem. 2nd ed. P. N. Hobson and C. S. Stewart, ed. Blackie Academic and Professional, London, UK.

Stewart, C. S., H. J. Flint, and M. P. Bryant. 1997. The rumen bacteria. Page 45 in The Rumen Microbial Ecosystem. 2nd ed. P. N. Hobson and C. S. Stewart, ed. Blackie Academic and Professional, London, UK.

Stone, W. C. 2004. Nutritional approaches to minimize subacute ruminal acidosis and laminitis in dairy cattle. J. Dairy Sci. 87(E. Suppl.):E13-E26.

Van Soest, P. J., J. B. Robertson, and B. A. Lewis. 1991. Methods for dietary fiber, neutral detergent fiber, and nonstarch polysaccharides in relation to animal nutrition. J. Dairy Sci. 74:3583-3597. https://doi.org/10.3168/jds.S0022-0302(91)78551-2.

Wallace, R. J., and M. A. Cotta. 1989. Metabolism of nitrogen-containing compounds. Pages 217-250 in The Rumen Microbial Ecosystem. P. N. Hobson, ed. Elsevier Applied Science, New York, NY.

Weller, R. A., and A. F. Pilgrim. 1974. Passage of protozoa and volatile fatty acids from the rumen of the sheep and from a continuous in vitro fermentation system. Br. J. Nutr. 32:341-351.

Werner, R. A., B. A. Bruch, and W. A. Brand. 1999. ConFlo III-An interface for high precision d13c and d15n analysis with an extended dynamic range. Rapid Commun. Mass Spectrom. 13:1237-1241.

Williams, A. G., S. E. Withers, and G. S. Coleman. 1984. Glycoside hydrolases of rumen bacteria and protozoa. Curr. Microbiol. 10:287-293. 